\title{
Nonmonetary Job Characteristics and Employment Transitions at Older Ages
}

\author{
Marco Angrisani, Arie Kapteyn, and Erik Meijer
}




\title{
Nonmonetary Job Characteristics and Employment Transitions at Older Ages
}

\author{
Marco Angrisani \\ University of Southern California
}

Arie Kapteyn

University of Southern California

Erik Meijer

University of Southern California

September 2015

\author{
Michigan Retirement Research Center \\ University of Michigan \\ P.O. Box 1248 \\ Ann Arbor, MI 48104 \\ www.mrrc.isr.umich.edu \\ (734) 615-0422
}

\section{Acknowledgements}

The research reported herein was performed pursuant to a grant from the U.S. Social Security Administration (SSA) funded as part of the Retirement Research Consortium through the University of Michigan Retirement Research Center (5 RRC08098401-07). The opinions and conclusions expressed are solely those of the author(s) and do not represent the opinions or policy of SSA or any agency of the Federal Government. Neither the United States Government or any agency thereof, or any of their employees, makes any warranty, express or implied, or assumes any legal liability or responsibility for the accuracy, completeness, or usefulness of the contents of this report. Reference herein to any specific commercial product, process or service by trade name, trademark, manufacturer, or otherwise does not necessarily constitute or imply endorsement, recommendation or favoring by the United States Government or any agency thereof.

\section{Regents of the University of Michigan}

Michael J. Behm, Grand Blanc; Mark J. Bernstein, Ann Arbor; Laurence B. Deitch, Bloomfield Hills; Shauna Ryder Diggs, Grosse Pointe; Denise Ilitch, Bingham Farms; Andrea Fischer Newman, Ann Arbor; Andrew C. Richner, Grosse Pointe Park; Katherine E. White, Ann Arbor; Mark S. Schlissel, ex officio 


\title{
Nonmonetary Job Characteristics and Employment Transitions at Older Ages
}

\begin{abstract}
This paper studies to what extent job characteristics such as physical and cognitive demands, use of technologies, responsibility, difficulty, stress, peer pressure, and relations with co-workers are related to full or partial retirement. We study employment transitions and retirement expectations of older workers by exploiting the wealth of information about individuals older than the age of 50 in the Health and Retirement Study (HRS), and characteristics of different occupations provided by the Occupation Information Network ( $\mathrm{O}^{*}$ NET) database. Controlling for basic demographics, wages, benefits, health, cognitive ability, personality, and other personal characteristics, we find strong and statistically significant relationships between labor force transitions and job characteristics. These relationships are typically more pronounced and more precisely estimated when we use objective job attributes taken from the O*NET than when we use self-reported job characteristics taken from the HRS, but self-reported characteristics are more strongly related to moves from full-time to part-time employment. Using expected retirement age or subjective probabilities of working full-time at older ages gives similar results to using actual labor force transitions as the dependent variable. The estimated effects of job characteristics are again stronger and more robust to alternative specifications when measures of job attributes are taken from the O*NET than from the HRS. Our findings suggest that nonmonetary job characteristics are important determinants of labor supply decisions at older ages, but our analysis is still preliminary in its attempt to uncover causal relationships: Unobservable individual characteristics responsible for sorting into specific occupations may also shape retirement decisions.
\end{abstract}

\section{Citation}

Angrisani, Marco, Arie Kapteyn, and Erik Meijer. 2015. "Nonmonetary Job Characteristics and Employment Transitions at Older Ages." Ann Arbor, MI. University of Michigan Retirement Research Center (MRRC) Working Paper, WP 2015-3**.

http://www.mrrc.isr.umich.edu/publications/papers/pdf/wp3**.pdf 


\section{Introduction}

Retirement decisions are informed by the different opportunities, resources, costs, and rewards that jobs provide. These are not confined to just monetary incentives, but include attributes of job tasks and of the work environment that ultimately affect the well-being and job satisfaction of workers. Job characteristics such as autonomy, skill variety, task significance and difficulty, stress and physical demands, peer pressure, and relations with co-workers, play a crucial role in

determining commitment to work, especially for individuals on the verge of retirement. To fully comprehend the process by which individuals exit the labor force, it is necessary to incorporate such attributes and their interactions with individual characteristics into retirement models, and to infer the way in which they influence the nature and timing of the labor-force withdrawal process.

While Social Security rules (Gruber and Wise, 2004), private pension arrangements (Lumsdaine and Mitchell, 1999), and health shocks (Currie and Madrian, 1999) are often cited as main predictors of the choice to exit the labor force, there exists relatively little research documenting the extent to which the work environment itself influences this decision. Moreover, the existing studies have focused only on a few dimensions and produced mixed results depending on whether job attributes are occupation-specific descriptors or individual-specific assessments of working conditions. Quinn (1978) finds that workers with repetitive jobs, high physical demand, and low autonomy tend to retire earlier. Bartel (1982) examines quitting decisions of young and middle-aged men in relation to their non-wage job characteristics. She finds that young men are more likely to quit repetitive jobs, while their older counterparts are less likely to remain in a job with unfavorable working conditions. Similarly, Filer and Petri (1988) document a strong relationship between job characteristics, such as intense physical demands, stress, and repetitive working conditions, and early retirement. Hayward et al. (1989) estimate that workers in more substantively complex and less physically demanding occupations delay retirement. On the other hand, Hurd and McGarry (1993) find only a weak association between self-reported job attributes and subjective probabilities of working after ages 62 and 65 . More recently, Blekesaune and Solem (2005) use administrative data from Norway and confirm that job strains do influence labor-force withdrawal. Specifically, individuals in highly physically demanding jobs retire earlier, often with a disability pension. Workers facing low autonomy also seek an early exit from the labor force and do so through early retirement schemes. Angrisani et 
al. (2013) look at subjective reports of job characteristics and find some of these to be strong predictors of labor force transitions. They also present evidence that these estimated effects are more pronounced for individuals with certain personality traits.

Work conditions may impact one's motivation and willingness to continue to pursue their career job. This may induce some to seek out alternative employment ("bridge” or part-time jobs) and others to retire altogether. Whether one or the other option prevails hinges crucially on individuals' financial needs and proclivity to work, as well as on the perceptions workers have about job opportunities and working conditions at older ages. Because of data limitations, early studies have lacked important explanatory variables, such as pension arrangements, detailed health information, cognitive ability, and other individual-specific traits, which, if not accounted for, are bound to confound the effect of nonmonetary job characteristics on labor supply decisions at older ages. Also, they have not examined the extent to which job characteristics affect transitions into part-time alongside with transitions into retirement. With the exception of Hurd and McGarry (1993) and Angrisani et al. (2013), they have overlooked the relationship between job attributes and expectations about future retirement. Finally, no study has assessed the relative importance of "objective" job characteristics versus "subjective" perceptions of working conditions in shaping mode and timing of labor force withdrawal.

We study employment transitions and retirement plans of older workers by exploiting the wealth of information about individuals older than 50 in the Health and Retirement Study (HRS), and various features of jobs in different occupations provided by the Occupation Information Network ( $\mathrm{O}^{*} \mathrm{NET}$ ) database. The HRS is a longitudinal study of a representative sample of the United States population older than 50. It surveys individuals on a variety of economic, health, and social outcomes, including employment, income, housing and financial wealth, physical and mental health, pension arrangements, health-insurance status, subjective expectations about working at older ages, and retirement plans. Because of its longitudinal dimension and richness of information, it constitutes an ideal dataset for analyzing changes in labor-force status and the formation of retirement expectations. It permits an analysis of the effects of nonmonetary job characteristics, while accounting for many other determinants, such as economic, social and health factors, and individual traits and preferences. 
A key feature of the HRS for the purposes of our study is the elicitation of individuals' assessments of several aspects of their own jobs beyond monetary compensation. At the same time, the availability of occupation codes allows us to link the HRS to the O*NET database and to obtain a broad range of representative job characteristics for each occupation. Self-reported measures of job attributes may better reflect heterogeneity within occupational categories. Moreover, individuals' labor-supply decisions may be more strongly related to subjective perceptions of job conditions than to objective characteristics of the work environment. On the other hand, the way respondents report information about their jobs and workplaces may be a function of their ability, personality, and other (unobserved) traits: What is stimulating or challenging for some workers may be demanding or unpleasant for others. If so, the effect of self-reported job conditions on labor supply decisions may be confounded by individual heterogeneity in preferences, personality, and perceptions of the work environment. For policy making it is arguably more important to assess how labor force transitions are influenced by objective characteristics than by subjective perceptions. Yet, evaluating the extent to which selfreported job attributes and the underlying individual heterogeneity in reporting behavior predict labor-force transitions constitutes a valuable and informative exercise.

In order to investigate the relationship between nonmonetary job characteristics and labor force status transitions, as well as retirement plans, we run separate analyses using both "subjective" (from the HRS) and "objective" (from the O*NET) measures of job attributes. By comparing the results of these two parallel analyses, we gauge the relative importance of individuals' perceptions about their work environments and objective job characteristics in driving labor-supply decisions at older ages.

The contribution of our paper is twofold. First, we provide a very comprehensive examination of the various nonmonetary, work-related factors that affect the dynamics of laborforce withdrawal at older ages and of whether the effects are driven by individuals' perceptions and/or by objective job demands and characteristics. Second, we consider a variety of outcomes including transitions from full-time work to part-time and to retirement, subjective expectations about working after age 62 and 65, and planned age for exiting the labor force. To the best of our knowledge, this is the first systematic attempt at assessing how strong retirement choices are related to working conditions and at identifying which job characteristics are most likely to influence labor-force attachment of individuals on the verge of retirement. 
We find strong and statistically significant relationships between labor-force transitions and job characteristics. These relationships are more pronounced and more precisely estimated when we use objective job attributes taken from the $\mathrm{O}^{*} \mathrm{NET}$ than when we use self-reported job characteristics taken from the HRS. Also, objective measures are more powerful determinants of retirement, while self-reported ones are more important drivers of the decision to move from full-time to part-time. Objective physical demands increase the likelihood of a transition from full-time employment to retirement within the next two years. Perception of on-the-job physical effort increases the probability of moving to part-time, but is not associated with transitions into retirement. The objective measure of computer use is associated with a higher likelihood of remaining full-time employed and a lower one of retiring, but it is not linked to the decision of moving to part-time. Its self-reported counterpart is positively related to the probability of remaining in full-time employed and negatively related to the probability of moving to part-time, but it is not linked to the decision of retiring. Individuals in occupations that require people skills and more frequent interactions with others are less likely to retire. Perceived task difficulty and job-related stress increase the probability of exiting the labor force altogether, while the “objective” degree of on-the-job responsibility increases the probability of moving to part-time. Older workers that feel discriminated against because of their age are less likely to remain in full-time employment and more likely to retire.

The results of the analysis using time until planned retirement age and subjective probabilities of working full-time at older ages are in line with those focusing on actual labor force transitions. Also for these outcomes, the estimated effects of job characteristics are stronger and more robust to alternative specifications when measures of job attributes are taken from the O*NET rather than from the HRS. Physical demands decrease time until planned retirement age and the subjective probability of working full-time after age 62 and 65 . Social skills requirements and cognitive demands are associated with greater time until planned retirement age, as well as with higher likelihood of working past age 65.

Our findings suggest that nonmonetary job characteristics and the work environment are important drivers of the labor-force withdrawal process. In view of the documented empirical evidence, working conditions may represent the target of potential interventions aiming at prolonging workers' attachment to the labor force. This represents valuable knowledge for 
policymakers: Encouraging late retirement is at the top of their agenda as the population ages and concerns about the sustainability of social programs for the elderly rise.

\section{Data}

\subsection{HRS Data}

We use data from the Health and Retirement Study (HRS), a multipurpose, longitudinal household survey representing the U.S. population older than 50. Since 1992, the HRS has surveyed age-eligible respondents and their spouses every two years to track transitions from work into retirement, to measure economic well-being in later life, and to monitor changes in health status as individuals age. Initially, the HRS consisted of individuals born between 1931 and 1941 and their spouses, but additional cohorts have been added in 1993, 1998, 2004, and 2010, the youngest representing individuals born between 1954 and 1959.

We primarily use data from the RAND version of the HRS, version N (Chien et al., 2014). The RAND HRS is a large, user-friendly subset of the HRS that combines data from all waves, adds information that may have been provided by the spouse to the respondent's record and has consistent imputation of financial variables. We complement this data set with additional variables from the employment module of each wave obtained from the RAND FAT files. These are partially preprocessed files with all the raw HRS data of each wave combined into a single respondent-level file.

In 2004, the HRS piloted a supplemental, self-administered questionnaire that was left with the respondent after the completion of an in-person core interview. This Leave-Behind (LB) Questionnaire asks about respondents' evaluations of their life circumstances, subjective wellbeing, and lifestyle. We rely on the LB questionnaire for measures of personality traits. Since 2004, the LB questionnaire has been administered in each biennial wave to a randomly selected rotating 50 percent of the core sample who were assigned to an in-person interview. This design implies that, for each respondent, LB measures are available every other wave (or every four years).

The HRS core questionnaire provides us with information about individual demographics, labor force status, pension arrangements, financial situation, health status, and retirement 
expectations. We assign respondents to different labor-force status groups according to their employment situation. In doing so, we combine the RAND HRS definition of labor-force status with information about the number of working hours per week and the number of weeks worked in a year on the main job. Specifically, we classify individuals as full-time employees if they work at least 35 hours per week and 36 weeks per year on their main job. We follow Maestas (2010) and classify individuals as part-time employees if they work either less than 35 hours per week or less than 36 weeks per year on their main job. We classify individuals as retired if they are defined as such according to the RAND HRS labor-force status variable. We form a final group consisting of those who are either out of the labor force or unemployed according to the RAND HRS labor force status variable. We exclude from the sample self-employed and disabled individuals. This leaves us with a sample of 10,496 individuals and 24,016 individual-time observations.

Our first outcome of interest is the transition across two periods from full-time employment to one of four mutually exclusive labor force states, namely: full-time employment, part-time employment, retirement, unemployed/out of the labor force. There are 6,491 workers with valid transitions for a total of 13,498 observations. Table 1 shows the prevalence of these transitions in our sample, aggregated across all waves in our sample. The majority of full-time employees are still employed full-time in the subsequent wave, with this percentage decreasing with age. About half of the observed labor-force status changes are to retirement, while more than a third are to part-time, especially among relatively older and female workers. Transitions from full-time employment to unemployment/out of the labor force are less frequent.

Table 1: Labor force status transitions from full-time employment

\begin{tabular}{|c|c|c|c|c|c|c|c|c|c|c|}
\hline \multirow{2}{*}{$\begin{array}{l}\text { Next wave } \\
\text { labor force status }\end{array}$} & \multicolumn{2}{|c|}{ All } & \multicolumn{2}{|c|}{ Age 51-61 } & \multicolumn{2}{|c|}{ Age 62-79 } & \multicolumn{2}{|c|}{ Males } & \multicolumn{2}{|c|}{ Females } \\
\hline & $\mathrm{N}$ & $\%$ & $\mathrm{~N}$ & $\%$ & $\mathrm{~N}$ & $\%$ & $\mathrm{~N}$ & $\%$ & $\mathrm{~N}$ & $\%$ \\
\hline Full-time employee & 10,290 & 76 & 8,233 & 81 & 2,057 & 60 & 4,876 & 77 & 5,414 & 75 \\
\hline Part-time employee & 1,076 & 8 & 636 & 6 & 440 & 13 & 393 & 6 & 683 & \\
\hline Retired & 1,582 & 12 & 786 & 8 & 796 & 23 & 765 & 12 & 817 & 11 \\
\hline Unemployed/Out LF & 550 & 4 & 437 & 4 & 113 & 3 & 251 & 4 & 299 & \\
\hline Total & 13,498 & 100.0 & 10,092 & 100.0 & 3,406 & 100.0 & 6,285 & 100.0 & 7,213 & 100.0 \\
\hline
\end{tabular}


The HRS elicits planned retirement age, as well as the subjective probabilities of working full-time after age 62 and 65 . We examine how retirement intentions differ for individuals facing different working conditions by considering distance in years from planned retirement and the probability of working full-time at older ages. The sample of workers ages 51-79 for whom planned retirement age is available consists of 6,990 individuals and 12,005 individual-time observations. Average time until planned retirement is 6.5 years, with a median of 6 and a standard deviation of 5. Subjective probabilities of working full-time after age 62 and 65 are elicited for workers younger than 62 and 65, respectively. The available sample consists of 7,881 individuals and 15,240 individual-time observation in the first case, and of 8,808 individuals and 18,124 individual-time observations in the second. Self-reported probabilities are bunched at 0 , 50, and 100 percent, although peaks at 20, 40, 60, and 80 are also evident. Such reporting behavior is also observed for other probabilistic expectations within the HRS, as well as in other surveys (Manski, 2004). The average (median) probability of working full-time after age 62 is 53 percent (50 percent) with a standard deviation of 37\%. The average (median) probability of working full-time after age 65 is 35\% (25\%) with a standard deviation of 35\%.

The HRS core questionnaire asks respondents who are currently working for pay about several aspects of their jobs. These include information about employer-provided pension plans and health insurance, hourly wage, physical and mental requirements, physical and cognitive demands, incentives and pressure to retire, and level of work-related stress. Table 2 below shows descriptive statistics for these nonmonetary, self-reported job characteristics. We will study to what extent self-reported and "objective" (described below in Section 2.2) nonmonetary job conditions influence employment transitions and retirement intentions of older workers, keeping monetary incentives and other potential confounders constant. The richness of information available in the HRS allows us to control for the economic, health, and family circumstances that are bound to affect labor-supply decisions. Moreover, the HRS contains various measures of individual traits. Some, like risk aversion and length of financial planning horizon, are available in the core questionnaire. Others, such as personality traits, can be found in the LB questionnaire. Specifically, respondents are asked to rate themselves on a series of adjectives associated with the Big Five personality traits: openness to experience, conscientiousness, extraversion, agreeableness, and neuroticism (emotional stability). Following the procedure described in the appendix, we transform individual self-ratings into five indices corresponding to the Big Five 
personality traits. Because of the rotational design of the LB questionnaire, we can only measure personality every other wave. In order to maximize the sample size for our analysis, we assume that personality traits are stable over time and assign to each individual the average of their available personality measures over the observation period. Our assumption receives support from recent studies demonstrating that Big Five personality traits are relatively stable for working-age adults (Cobb-Clark and Schurer, 2012) and that stability peaks between the ages of 60 and 70 (Lucas and Donnellan, 2011), a range covering 70\% of our sample.

Table 2: Self-Reported Job Characteristics - Descriptives

\begin{tabular}{c|ccc}
\hline & Mean & Median & Std. Dev. \\
\hline Physical Effort & 1.93 & 1.67 & 0.89 \\
Good Eyesight & 3.55 & 4.00 & 0.84 \\
Intense Concentration & 3.37 & 4.00 & 0.84 \\
People Skills & 3.59 & 4.00 & 0.77 \\
Useof Computer & 2.59 & 3.00 & 1.70 \\
Difficulty/Stress & 2.61 & 2.50 & 0.53 \\
Age Discrimination & 1.99 & 2.00 & 0.59 \\
\hline
\end{tabular}

\subsection{O*NET Data}

The Occupation Information Network ( $\left.\mathrm{O}^{*} \mathrm{NET}\right)$ database contains information about worker characteristics and job characteristics by detailed occupation. It is developed under the auspices of the Department of Labor (DOL). After some pretests, full-scale data collection started in 2001. The database is regularly expanded and updated. Data are collected from samples of workers in the occupations and from outside experts. The data are available from http://www.onetcenter.org.

We use version 19.0 of the O*NET, which was released in July 2014. It has 1,110 detailed occupations and it measures 256 characteristics of those occupations (or the workers in those occupations), although not all characteristics are measured for each occupation. Generally, it provides a distribution of the characteristic for an occupation, for example, mean and standard deviation, or probabilities of discrete values. For some characteristics, there are two aspects: level and importance.

In order to obtain a practically manageable set of variables for our analyses, we implement a few data reduction steps. When there are both level and importance measures, we only use the level. Then for each characteristic, we only use the mean, treating categorical 
variables as interval-scaled. Through a series of crosswalk files, we link each O*NET occupation to 1980 and 2002 three- or four-digit Census occupation codes, which in turn determine the occupation codes used in the HRS public-release data. The latter aggregate occupations to nine, 17, or 25 broad categories, depending on when the occupational information of the respondent was collected. We then compute the unweighted mean of each characteristic across occupations in each broad category. These scores are then merged to the HRS data.

Table 3: O*NET Indices of Workers' Characteristics and Requirements

\begin{tabular}{|c|c|}
\hline Index & Composition $^{a}$ \\
\hline Workers' Cognition & $\begin{array}{l}\text { Verbal abilities; Idea generation and reasoning abilities; Quantitative } \\
\text { abilities; Memory; Spatial abilities; Attentiveness }\end{array}$ \\
\hline $\begin{array}{l}\text { Workers' Psychomotor } \\
\text { Ability }\end{array}$ & $\begin{array}{l}\text { Fine manipulative abilities; Control movement abilities; Reaction time } \\
\text { and speed abilities }\end{array}$ \\
\hline $\begin{array}{l}\text { Workers' Physical } \\
\text { Ability }\end{array}$ & $\begin{array}{l}\text { Physical strength abilities; Endurance; } \\
\text { Flexibility, balance, and coordination }\end{array}$ \\
\hline Workers' Eyesight & Visual abilities \\
\hline $\begin{array}{l}\text { Workers' Sensory } \\
\text { Perception }\end{array}$ & Perceptual abilities; Auditory and speech abilities \\
\hline Required Cognition & $\begin{array}{l}\text { Basic skills (Content and Process); Complex problem solving skills; } \\
\text { Judgment and decision making; } \\
\text { Required level of education }\end{array}$ \\
\hline Required Social Skills & $\begin{array}{l}\text { Social perceptiveness; Coordination; Persuasion; Negotiation; } \\
\text { Instructing; Service Orientation }\end{array}$ \\
\hline Required Experience & $\begin{array}{l}\text { Related work experience; On-site or in-plant training; } \\
\text { On-the-job training }\end{array}$ \\
\hline
\end{tabular}

\footnotetext{
${ }^{a}$ Many of these components are themselves clusters of subcomponents. In the aggregation, we treat all lowest-level subcomponents equally, but we do not list all of them here.
} 
We identify a number of clusters of related characteristics, which we combine in summary indices. Characteristics generally have a similar or identical number of categories and coding scheme within each cluster, so we simply use the unweighted means of the variables in each cluster, reverse coding characteristics if necessary. We form indices using descriptors from three areas of the O*NET Content Model: 1) qualifications and interests of the typical worker; 2) worker requirements; 3) job activities and demands. The indices we use in the analysis and their descriptive statistics are listed in Tables 3-6.

Table 4: O*NET Workers’ Characteristics and Requirements - Descriptives

\begin{tabular}{c|ccc}
\hline & Mean & Median & Std. Dev. \\
\hline Workers' Cognition & 2.89 & 2.79 & 0.34 \\
Workers' Psychomotor Ability & 1.54 & 1.35 & 0.74 \\
Workers' Physical Ability & 1.05 & 0.74 & 0.63 \\
Workers' Eyesight & 1.69 & 1.62 & 0.41 \\
Workers' Sensory Perception & 2.33 & 2.32 & 0.21 \\
Required Cognition & 3.76 & 3.50 & 0.60 \\
Required Social Skills & 2.90 & 2.75 & 0.41 \\
Required Experience & 1.29 & 1.29 & 0.55 \\
\hline
\end{tabular}

\section{Econometric Specification}

Labor supply decisions and retirement plans at older ages depend on a number of factors, which, for simplicity, we aggregate into five broad categories: (1) compensation, pension arrangements, health insurance coverage, institutional incentives, and financial preparedness for retirement; (2) family circumstances and couple complementarities (e.g., preference for husband and wife to retire together); (3) match or mismatch between work ability and job demands; (4) individualspecific traits like personality, risk aversion, and planning horizon, which are bound to affect one's proclivity to work; and (5) costs of work as determined by the job attributes and the work environment faced by the individual. To disentangle the effect of nonmonetary job characteristics on labor supply decisions and retirement expectations from other potential determinants, in our empirical analysis we control for basic demographics, such as gender, age, education, and marital status, and, as much as the data allow us, for the factors (1) - (4) mentioned above.

In our baseline specification, we account for hourly wage, existence and type of employer-sponsored pension plan, employer-provided health insurance policy, and indicators for 
whether the individual is above the age of 62 (eligible for early Social Security claiming) and 65 (Medicare eligibility). We also include age difference with the spouse and an indicator for whether the spouse is working to capture, in addition to marital status, other couple incentives/disincentives to withdraw from the labor force. We proxy individual ability to work with self-reported health status and cognitive test scores. Finally, we add time fixed-effects to net out trends in retirement behavior and expectations over the observation period.

Table 5: O*NET Indices of Job Characteristics and Demands

\begin{tabular}{|c|c|}
\hline Index & Composition $^{a}$ \\
\hline $\begin{array}{l}\text { Cognitive } \\
\text { demands }\end{array}$ & $\begin{array}{l}\text { Information input; Mental processes; } \\
\text { Documenting/recording information }\end{array}$ \\
\hline Physical demands & $\begin{array}{l}\text { Performing physical and manual work activities; } \\
\text { Time spent in body positions }\end{array}$ \\
\hline $\begin{array}{l}\text { Working with } \\
\text { computer }\end{array}$ & Interacting with computers \\
\hline $\begin{array}{l}\text { Working with } \\
\text { equipment }\end{array}$ & $\begin{array}{l}\text { Drafting, laying out, and specifying technical devices, parts, and } \\
\text { equipment; Repairing and maintaining mechanical equipment; Repairing } \\
\text { and maintaining electronic equipment }\end{array}$ \\
\hline $\begin{array}{l}\text { Interaction with } \\
\text { others }\end{array}$ & $\begin{array}{l}\text { Interacting with others; Communication methods; } \\
\text { Contact with others; Job interactions }\end{array}$ \\
\hline Responsibility & $\begin{array}{l}\text { Responsibility for others; Criticality of position; } \\
\text { Routine versus challenging work }\end{array}$ \\
\hline Difficulty/stress & Conflictual contact; Level of competition; Pace and scheduling \\
\hline
\end{tabular}

\footnotetext{
${ }^{a}$ Many of these components are themselves clusters of subcomponents. In the aggregation, we treat all lowest-level subcomponents equally, but we do not list all of them here.
}

In a second and richer specification, we also account for total household wealth and other household income (except individual earnings) ${ }^{1}$. In our third and most complete specification, we additionally control for individual-specific characteristics that may shape retirement preferences, namely the Big Five personality traits, attitude towards risk, and planning horizon for family spending and savings. While this list is not exhaustive, it includes several individual-

\footnotetext{
${ }^{1}$ In the interest of space, we do not report the results of this specification. They do not differ significantly from those shown in the tables below and are available upon request.
} 
specific characteristics that may drive selection into certain occupations and correlate with a taste for leisure versus work. The HRS provides other measures of individual traits. Specifically, the LB questionnaire includes proxies for optimism and determination and elicits frequency and type of social interactions outside the job ${ }^{2}$. We leave the inclusion of these variables in our analysis for future research.

Table 6: O*NET Job Characteristics - Descriptives

\begin{tabular}{c|ccc}
\hline & Mean & Median & Std. Dev. \\
\hline Cognitive Demands & 3.52 & 3.29 & 0.53 \\
Physical Demands & 2.47 & 2.25 & 0.52 \\
Working with Computer & 2.88 & 3.15 & 0.77 \\
Working with Equipment & 1.46 & 1.24 & 0.72 \\
Interaction with Others & 3.32 & 3.16 & 0.46 \\
Responsibility & 3.04 & 3.06 & 0.19 \\
Difficulty/Stress & 2.50 & 2.48 & 0.09 \\
\hline
\end{tabular}

We estimate multinomial discrete choice models for actual employment transitions across two periods and linear regression models for planned retirement age and subjective probabilities of working at older ages. We assume that the determinants of these outcomes are individual demographics, health, cognitive abilities, family/couple circumstances and attitudinal traits $(X)$, monetary job attributes and institutional incentives $(M J)$ and nonmonetary job characteristics (NonMJ), whose effects represent the parameters of interest in our analysis. We use self-reported measures of nonmonetary job characteristics taken from the HRS, as well as objective descriptors of jobs taken from the O*NET. Both sets of measures are standardized to ease interpretation and comparability.

In our regressions, we include one job characteristic, whether subjectively or objectively measured, at a time. This choice is imposed by the severe collinearity issues that arise when all O*NET job attributes from one of the three O*NET Content Model areas (qualifications and interests of the typical worker; worker requirements; job activities and demands) feature simultaneously in the model. We do not encounter collinearity problems when we include all

\footnotetext{
${ }^{2}$ Krueger and Schkade (2008) exploit measures of social interactions outside the job to study whether more socially interactive individuals sort into more interactive jobs.
} 
HRS self-reported job characteristics as regressors and the estimated coefficients do not differ significantly from those reported in the text.

When examining employment transitions, we model the probability that a full-time employee transits to a different labor force status across two periods, namely:

$$
P_{i j, t+1}=\operatorname{Pr}\left(Y_{i, t+1}=j \mid X_{i, t}, \mathrm{MJ}_{i, t}, \operatorname{NonMJ}_{i, t}\right)=F_{j}\left(X_{i, t}, \mathrm{MJ}_{i, t}, \operatorname{NonMJ}_{i, t} ; \theta\right),
$$

where $Y_{i, t+1}$ is the labor force status at time $t+1, j=1$ (full-time), 2 (part-time), 3 (retired), or 4 (out of the labor force or unemployed), and explanatory variables are observed at time $t$. The function $F_{j}$ is a probability function depending on a vector of unknown parameters $\theta$. We adopt a Multinomial Logit model, hence:

$$
F_{j}\left(X_{i, t}, \mathrm{MJ}_{i, t}, \mathrm{NonMJ}_{i, t} ; \theta\right)=\frac{\exp \left(V_{i j}\right)}{\sum_{k=1}^{4} \exp \left(V_{i k}\right)}, j=1, \ldots, 4
$$

where

$$
V_{i j}=X_{i, t}^{\prime} \alpha_{j}+\mathrm{MJ}_{i, t}^{\prime} \beta_{j}+\operatorname{NonMJ}_{i, t}^{\prime} \gamma_{j}+t^{\prime} \delta_{j}
$$

and $\theta=\left(\begin{array}{c}\alpha_{j} \\ \beta_{j} \\ \gamma_{j} \\ \delta_{j}\end{array}\right)$

The expression

$$
\mathrm{ME}_{i j z, t}(\theta)=\frac{\partial F_{j}\left(X_{i, t}, \mathrm{MJ}_{i, t}, \operatorname{NonMJ}_{i, t} ; \theta\right)}{\partial Z_{i, t}} .
$$

is the marginal effect of a variable $Z$ on choice $j$ for individual $i$ in period $t$. We estimate and report in the tables below the average marginal effects, that is:

$$
\overline{\mathrm{ME}}_{j z}(\hat{\theta})=\frac{1}{N} \sum_{i=1}^{N} \frac{1}{T_{i}} \sum_{t=1}^{6} D_{i, t} \mathrm{ME}_{i j z, t}(\hat{\theta}),
$$

where $N$ is the number of individuals in our sample, $T_{i}$ is the number of transitions in our sample for individual $i$ and $D_{i t}=1$ if the transition between waves $t$ and $t+1$ of individual $i$ is in our sample and 0 otherwise. Since the same individual $i$ may be represented in multiple observations 
(from different waves), standard errors are computed by the delta method and clustered at the respondent level.

When studying retirement intentions, we use linear regression models of the form:

$$
Y_{i, t}=X_{i, t}^{\prime} a+\operatorname{MJ}_{i, t}^{\prime} b+\operatorname{NonMJ}_{i, t}^{\prime} c+t^{\prime} d+\varepsilon_{i, t},
$$

where $\varepsilon_{i, t}$ is an idiosyncratic error term. In this case, we are primarily interested in the coefficients $c$, representing the effect of nonmonetary job attributes on either time until planned retirement or subjective expectations of working at older ages, over and above the effects of individual demographics, family and economic circumstances, abilities and personality, as well as monetary job characteristics. Again, standard errors are clustered at the individual level.

\section{Results: Labor Force Transitions}

In this section, we present the results of the analysis focusing on labor force transitions. Tables $7 \mathrm{a}$ and $7 \mathrm{~b}$ show the estimated marginal effects for the set of controls that will also be present in all other regressions. These estimated coefficients may help understand the relative importance of job characteristics, whether subjectively reported or objectively measured, in driving this first outcome of interest.

Some interesting patterns emerge. Female workers are less likely to remain employed full-time and more likely to move to a part-time job. As individuals age, they tend to either move to part-time or to retire altogether. Full-time employees older than 65 are more likely to remain in full-time employment and less-likely to retire. Possible explanations for this finding are that these workers have a taste for work or may hold better jobs. As a consequence, their retirement decisions are driven to a lesser extent by crossing the Social Security early- and full-retirement age and by Medicare eligibility. More educated workers are more likely to move to part-time and less likely to retire. Being in a couple decreases the likelihood of remaining employed full-time and increases the likelihood of moving to part-time or retirement (although the latter effect is not precisely 
Table 7a: Labor Force Transitions - Controls

\begin{tabular}{|c|c|c|c|c|}
\hline \multirow[t]{2}{*}{ Covariate } & \multicolumn{4}{|c|}{ Transition from Full-Time to: } \\
\hline & Full-Time & e Part-Time & Retired & ./Out \\
\hline$\overline{\text { Female }}$ & $\begin{array}{c}-0.037^{* * *} \\
(0.009)\end{array}$ & $\begin{array}{c}0.045^{* * *} \\
(0.006)\end{array}$ & $\begin{array}{l}-0.008 \\
(0.007)\end{array}$ & $\begin{array}{c}-0.000 \\
(0.004)\end{array}$ \\
\hline Age & $\begin{array}{c}-0.020^{* * * *} \\
(0.001)\end{array}$ & $\begin{array}{c}0.006^{* * * *} \\
(0.001)\end{array}$ & $\begin{array}{c}0.016 * * * \\
(0.001)\end{array}$ & $\begin{array}{l}-0.001 * \\
(0.001)\end{array}$ \\
\hline Spouse Age Diff. & $\begin{array}{l}0.001^{*} \\
(0.001)\end{array}$ & $\begin{array}{l}0.001^{*} \\
(0.001)\end{array}$ & $\begin{array}{c}-0.002^{* * * *} \\
(0.001)\end{array}$ & $\begin{array}{c}0.000 \\
(0.000)\end{array}$ \\
\hline Age $\geq 62$ & $\begin{array}{l}-0.016 \\
(0.014)\end{array}$ & $\begin{array}{c}0.009 \\
(0.009)\end{array}$ & $\begin{array}{c}0.009 \\
(0.010)\end{array}$ & $\begin{array}{l}-0.002 \\
(0.007)\end{array}$ \\
\hline Age $\geq 65$ & $\begin{array}{c}0.074 * * * \\
(0.013)\end{array}$ & $\begin{array}{c}-0.020^{* *} \\
(0.008)\end{array}$ & $\begin{array}{c}-0.056^{* * * *} \\
(0.008)\end{array}$ & $\begin{array}{c}0.002 \\
(0.008)\end{array}$ \\
\hline High School & $\begin{array}{c}0.010 \\
(0.013)\end{array}$ & $\begin{array}{l}-0.001 \\
(0.008)\end{array}$ & $\begin{array}{c}0.005 \\
(0.010)\end{array}$ & $\begin{array}{c}-0.013^{* *} \\
(0.006)\end{array}$ \\
\hline Some College & $\begin{array}{c}0.014 \\
(0.013)\end{array}$ & $\begin{array}{c}0.005 \\
(0.008)\end{array}$ & $\begin{array}{c}-0.010 \\
(0.010)\end{array}$ & $\begin{array}{l}-0.009 \\
(0.006)\end{array}$ \\
\hline College and Above & $\begin{array}{c}0.018 \\
(0.015)\end{array}$ & $\begin{array}{l}0.021^{* *} \\
(0.010)\end{array}$ & $\begin{array}{c}-0.033 * * * \\
(0.011)\end{array}$ & $\begin{array}{l}-0.006 \\
(0.007)\end{array}$ \\
\hline In a Couple & $\begin{array}{c}-0.029 * * \\
(0.011)\end{array}$ & $\begin{array}{c}0.018 * * * \\
(0.007)\end{array}$ & $\begin{array}{c}0.012 \\
(0.008)\end{array}$ & $\begin{array}{l}-0.002 \\
(0.006)\end{array}$ \\
\hline Spouse Working & $\begin{array}{l}0.025^{* *} \\
(0.010)\end{array}$ & $\begin{array}{c}-0.004 \\
(0.006)\end{array}$ & $\begin{array}{c}-0.019 * * \\
(0.007)\end{array}$ & $\begin{array}{c}-0.003 \\
(0.005)\end{array}$ \\
\hline Poor Health & $\begin{array}{c}-0.061^{* * * *} \\
(0.011)\end{array}$ & $\begin{array}{l}-0.007 \\
(0.007)\end{array}$ & $\begin{array}{c}0.056^{* * *} \\
(0.009)\end{array}$ & $\begin{array}{l}0.012^{* *} \\
(0.005)\end{array}$ \\
\hline Low Word Recall Score & $\begin{array}{c}0.013 \\
(0.008)\end{array}$ & $\begin{array}{c}0.003 \\
(0.005)\end{array}$ & $\begin{array}{l}-0.011^{*} \\
(0.006)\end{array}$ & $\begin{array}{l}-0.005 \\
(0.004)\end{array}$ \\
\hline Low Serial 7 Score & $\begin{array}{c}0.002 \\
(0.008)\end{array}$ & $\begin{array}{c}-0.002 \\
(0.005)\end{array}$ & $\begin{array}{c}0.003 \\
(0.006)\end{array}$ & $\begin{array}{l}-0.004 \\
(0.004)\end{array}$ \\
\hline Hourly Wage & $\begin{array}{c}0.009 \\
(0.008)\end{array}$ & $\begin{array}{c}-0.019 * * * \\
(0.006)\end{array}$ & $\begin{array}{c}0.020^{* * * *} \\
(0.006)\end{array}$ & $\begin{array}{c}-0.010^{* *} \\
(0.004)\end{array}$ \\
\hline DB Pension & $\begin{array}{c}-0.054^{* *} \\
(0.023)\end{array}$ & $\begin{array}{l}-0.020 \\
(0.014)\end{array}$ & $\begin{array}{c}0.073 * * * \\
(0.017)\end{array}$ & $\begin{array}{c}0.001 \\
(0.011)\end{array}$ \\
\hline DC Pension & $\begin{array}{l}-0.009 \\
(0.021)\end{array}$ & $\begin{array}{l}-0.023^{*} \\
(0.013)\end{array}$ & $\begin{array}{c}0.015 \\
(0.014)\end{array}$ & $\begin{array}{c}0.017 \\
(0.013)\end{array}$ \\
\hline DB/DC Pension & $\begin{array}{l}-0.033 \\
(0.030)\end{array}$ & $\begin{array}{c}-0.015 \\
(0.019)\end{array}$ & $\begin{array}{c}0.020 \\
(0.021)\end{array}$ & $\begin{array}{c}0.027 \\
(0.020)\end{array}$ \\
\hline Missing Pension Info & $\begin{array}{c}-0.052 * * \\
(0.023)\end{array}$ & $\begin{array}{c}0.011 \\
(0.012)\end{array}$ & $\begin{array}{c}0.001 \\
(0.015)\end{array}$ & $\begin{array}{l}0.040^{* *} \\
(0.017)\end{array}$ \\
\hline Emp. Health Ins. (R) & $\begin{array}{c}0.065^{* * *} \\
(0.012)\end{array}$ & $\begin{array}{c}-0.034 * * * \\
(0.008)\end{array}$ & $\begin{array}{c}-0.029 * * * \\
(0.009)\end{array}$ & $\begin{array}{c}-0.002 \\
(0.005)\end{array}$ \\
\hline Emp. Health Ins. (S) & $\begin{array}{c}0.016 \\
(0.010)\end{array}$ & $\begin{array}{l}-0.002 \\
(0.007)\end{array}$ & $\begin{array}{l}-0.006 \\
(0.007)\end{array}$ & $\begin{array}{l}-0.008^{*} \\
(0.005)\end{array}$ \\
\hline Time Fixed-Effects & $\mathrm{Y}^{\prime}$ & $Y^{\prime}$ & $\mathrm{Y}$ & $\mathrm{Y}$ \\
\hline $\mathrm{N}$ & 12000 & 12000 & 12000 & 12000 \\
\hline
\end{tabular}


Table 7b: Labor Force Transitions - Controls (cont.)

\begin{tabular}{lcccc}
\hline Covariate & \multicolumn{4}{c}{ Transition from Full-Time to: } \\
\cline { 2 - 5 } & Full-Time & Part-Time & Retired & Unemp/Out of LF \\
\hline Openness to Experience & 0.009 & -0.006 & -0.012 & $0.009^{*}$ \\
& $(0.012)$ & $(0.008)$ & $(0.009)$ & $(0.005)$ \\
Conscientiousness & 0.014 & 0.003 & $-0.019^{* *}$ & 0.002 \\
& $(0.013)$ & $(0.009)$ & $(0.010)$ & $(0.006)$ \\
Extraversion & -0.008 & 0.008 & 0.010 & $-0.010^{* *}$ \\
& $(0.011)$ & $(0.008)$ & $(0.009)$ & $(0.005)$ \\
Agreeableness & $0.021^{*}$ & -0.008 & $-0.019^{*}$ & 0.005 \\
& $(0.013)$ & $(0.009)$ & $(0.010)$ & $(0.006)$ \\
Neuroticism & 0.008 & $-0.010^{*}$ & -0.011 & $0.013^{* * *}$ \\
& $(0.009)$ & $(0.006)$ & $(0.007)$ & $(0.004)$ \\
High Risk Aversion & 0.003 & $-0.013^{*}$ & 0.009 & 0.002 \\
& $(0.010)$ & $(0.007)$ & $(0.007)$ & $(0.004)$ \\
Long Planning Horizon & $0.030^{* * *}$ & -0.007 & $-0.022^{* * *}$ & -0.000 \\
& $(0.009)$ & $(0.006)$ & $(0.007)$ & $(0.004)$ \\
\hline $\mathrm{N}$ & 8991 & 8991 & 8991 & 8991 \\
\hline
\end{tabular}

All the controls in Table 7a are included in Table 7b. Differences in sample size are due to missing individualspecific traits. Standard errors are clustered at the individual level and reported in parentheses. ***, **, and * indicate significance at the $1 \%, 5 \%$, and $10 \%$ level, respectively.

estimated). As the age difference with the spouse increases, the probability of retirement decreases. Also, having a spouse who works makes individuals substantially more likely to remain in full-time employment. This may indicate complementarities in spouses' preference for retirement. Poor health decreases the probability of remaining employed full-time by 6 percentage points. It increases the probability of retiring and becoming unemployed or moving out of the labor force by 5.5 and 1.2 percentage points, respectively. On the other hand, we do not observe any relationship between cognitive abilities and labor-force transitions.

As far as monetary job characteristics are concerned, a higher hourly wage is associated with a higher likelihood of retiring. Workers with an employer-provided defined-benefit pension plan are nearly 5.5 percentage points less likely to remain in their full-time job and 7.5 percentage points more likely to retire altogether. The opposite effect can be observed if the individual is covered by an employer-sponsored health insurance policy. In this case, the probability of remaining employed full-time is 6.5 percentage points higher, while the likelihoods of moving to part-time and retiring are about 3.5 and 3 percentage points lower, respectively. 
Table 8: Effect of Self-Reported Nonmonetary Job Characteristics on Labor Force Transitions

\begin{tabular}{llllc}
\hline Covariate & \multicolumn{4}{c}{ Transition from Full-Time to: } \\
\cline { 2 - 5 } & Full-Time & Part-Time & Retired & Unemp/Out of LF \\
\hline Specification I & \multicolumn{5}{c}{} & \\
\hline Physical Effort & $-0.013^{* * *}$ & $0.009^{* * *}$ & 0.005 & -0.001 \\
& $(0.004)$ & $(0.003)$ & $(0.003)$ & $(0.002)$ \\
\hline Good Eyesight & $-0.008^{*}$ & 0.000 & $0.006^{*}$ & 0.002 \\
& $(0.004)$ & $(0.003)$ & $(0.003)$ & $(0.002)$ \\
\hline Intense Concentration & -0.000 & -0.000 & -0.000 & 0.001 \\
& $(0.004)$ & $(0.003)$ & $(0.003)$ & $(0.002)$ \\
\hline People Skills & 0.003 & 0.003 & -0.000 & $-0.006^{* * *}$ \\
& $(0.004)$ & $(0.003)$ & $(0.003)$ & $(0.002)$ \\
\hline Use of Computer & $0.015^{* * *}$ & $-0.012^{* * *}$ & -0.005 & 0.002 \\
& $(0.005)$ & $(0.003)$ & $(0.003)$ & $(0.002)$ \\
\hline Difficulty/Stress & $-0.011^{* * *}$ & -0.001 & $0.009^{* * *}$ & 0.002 \\
& $(0.004)$ & $(0.003)$ & $(0.003)$ & $(0.002)$ \\
\hline Age Discrimination & $-0.014^{* * *}$ & 0.000 & $0.013^{* * *}$ & 0.001 \\
& $(0.004)$ & $(0.002)$ & $(0.003)$ & $(0.002)$ \\
\hline $\mathrm{N}$ & 12,000 & 12,000 & 12,000 & 12,000 \\
\hline Specification II & & & & \\
\hline Physical Effort & $-0.012^{* *}$ & $0.008^{* *}$ & 0.005 & -0.001 \\
& $(0.005)$ & $(0.003)$ & $(0.004)$ & $(0.002)$ \\
\hline Good Eyesight & -0.005 & -0.003 & $0.007^{*}$ & 0.001 \\
& $(0.005)$ & $(0.003)$ & $(0.004)$ & $(0.002)$ \\
\hline Intense Concentration & -0.003 & -0.001 & 0.002 & 0.001 \\
& $(0.005)$ & $(0.003)$ & $(0.004)$ & $(0.002)$ \\
\hline People Skills & -0.000 & 0.004 & 0.000 & $-0.004 *$ \\
& $(0.005)$ & $(0.004)$ & $(0.004)$ & $(0.002)$ \\
\hline Useof Computer & $0.016^{* * *}$ & $-0.011^{* * *}$ & -0.006 & 0.002 \\
& $(0.005)$ & $(0.004)$ & $(0.004)$ & $(0.002)$ \\
\hline Difficulty/Stress & $-0.012^{* *}$ & 0.000 & $0.012^{* * *}$ & -0.001 \\
& $(0.005)$ & $(0.003)$ & $(0.004)$ & $(0.002)$ \\
\hline Age Discrimination & $-0.013^{* * *}$ & 0.000 & $0.013^{* * *}$ & -0.000 \\
& $(0.005)$ & $(0.003)$ & $(0.004)$ & $(0.002)$ \\
\hline $\mathrm{N}$ & 8991 & 8991 & 8991 & 8991 \\
\hline
\end{tabular}

Specification I includes: gender, age, indicators for age above 62 and 65, education, marital status, age difference with the spouse, indicator for whether the spouse is working, health status, cognitive test scores (word recall and serial 7), hourly wage, type of employer-sponsored pension plan, indicators for whether the respondent and/or the spouse are covered by employer-provided health insurance, and time fixed effects. Specification II adds to the set of regressors personality traits, measures of risk aversion, and family financial planning horizon. Standard errors are clustered at the individual level and reported in parentheses. ${ }^{* * *}, * *$, and $*$ indicate significance at the $1 \%$, $5 \%$, and $10 \%$ level, respectively.

Personality traits are not strong predictors of labor force transitions. Conscientiousness and agreeableness increase the probability of staying employed full-time and lower the probability of retiring. A higher degree of emotional instability (neuroticism) is associated with a 
higher chance that a full-time employee transitions into unemployment or out of the labor force in the next period. Higher risk aversion decreases the likelihood of moving to part-time, but does not seem to affect the probability of retiring. Individuals with a financial planning horizon of at least five years are three percentage points more likely to remain in full-time employment and 2.2 percentage points less likely to retire.

Tables 8-11 show strong and statistically significant relationships between labor-force transitions and job characteristics. These relationships are more pronounced and more precisely estimated when objective job attributes taken from the O*NET are used than when self-reported job characteristics taken from the HRS are adopted. Also, objective measures are more powerful determinants of retirement, while self-reported ones are more important drivers of the decision to move from full-time to part-time.

Specifically, an increase of one standard deviation in the level of "objective" physical demand (whether measured by average workers' psychomotor and physical ability or by average job-related physical demand) decreases the probability of remaining in full-time employment by nearly two percentage points (Tables 9 and 10). It has a small, positive effect on the likelihood of moving to part-time (significant at $10 \%$ in Table 9). It increases the probability of retirement by 1.3/1.8 percentage points. This represents roughly a $13 \%$ change relative to the observed transition probability of retirement of $12 \%$. An increase of one standard deviation in the level of perceived on-the-job physical effort decreases the probability of remaining in full-time employment by 1.2 percentage points (Table 8), has no effect on the transition to retirement, and increases the probability of part-time work by 0.8 percentage points. This is a $10 \%$ change relative to the observed transition probability of moving to part-time of $8 \%$.

The O*NET measure of use of computer is associated with a higher likelihood of remaining in full-time employment and a lower probability of retiring, but it is not linked to the decision of moving to part-time. Its self-reported counterpart taken from the HRS is positively related to the probability of remaining in full-time employment and negatively related to the probability of moving to part-time, but it is not linked to the decision of retiring. The O*NET index "working with equipment" is strongly and positively correlated with physical demands (with a correlation coefficient of 0.8 ), but strongly and negatively correlated with use of computer (with a 
Table 9: Effect of Objective Workers' Characteristics and Requirements on Labor Force Transitions

\begin{tabular}{|c|c|c|c|c|}
\hline \multirow[t]{2}{*}{ Covariate } & \multicolumn{4}{|c|}{ Transition from Full-Time to: } \\
\hline & Full-Time & Part-Time & Retired & Unemp/Out of LF \\
\hline \multicolumn{5}{|l|}{ Specification I } \\
\hline Workers' Cognition & $\begin{array}{l}-0.001 \\
(0.005)\end{array}$ & $\begin{array}{l}0.009 * * * \\
(0.003)\end{array}$ & $\begin{array}{l}-0.007 * \\
(0.004)\end{array}$ & $\begin{array}{l}-0.001 \\
(0.002)\end{array}$ \\
\hline Workers’ Psychomotor Ability & $\begin{array}{l}-0.018 * * * \\
(0.004)\end{array}$ & $\begin{array}{c}0.005^{*} \\
(0.003)\end{array}$ & $\begin{array}{l}0.012 * * * \\
(0.003)\end{array}$ & $\begin{array}{c}0.000 \\
(0.002)\end{array}$ \\
\hline Workers’ Physical Ability & $\begin{array}{l}-0.021 * * * \\
(0.005)\end{array}$ & $\begin{array}{l}0.007^{* *} \\
(0.003)\end{array}$ & $\begin{array}{l}0.015 * * * \\
(0.003)\end{array}$ & $\begin{array}{l}-0.001 \\
(0.002)\end{array}$ \\
\hline Workers’ Eyesight & $\begin{array}{l}-0.019 * * * \\
(0.004)\end{array}$ & $\begin{array}{l}0.007^{* *} \\
(0.003)\end{array}$ & $\begin{array}{l}0.012 * * * \\
(0.003)\end{array}$ & $\begin{array}{c}0.001 \\
(0.002)\end{array}$ \\
\hline Workers' Sensory Perception & $\begin{array}{l}-0.015 * * * \\
(0.004)\end{array}$ & $\begin{array}{l}0.009 * * * \\
(0.003)\end{array}$ & $\begin{array}{l}0.006^{* *} \\
(0.003)\end{array}$ & $\begin{array}{l}-0.000 \\
(0.002)\end{array}$ \\
\hline Required Cognition & $\begin{array}{c}0.001 \\
(0.005)\end{array}$ & $\begin{array}{l}0.009 * * * \\
(0.003)\end{array}$ & $\begin{array}{l}-0.008^{* *} \\
(0.004)\end{array}$ & $\begin{array}{l}-0.002 \\
(0.002)\end{array}$ \\
\hline Required Social Skills & $\begin{array}{c}0.005 \\
(0.004)\end{array}$ & $\begin{array}{l}0.006^{* *} \\
(0.003)\end{array}$ & $\begin{array}{l}-0.009 * * * \\
(0.003)\end{array}$ & $\begin{array}{l}-0.002 \\
(0.002)\end{array}$ \\
\hline Required Experience & $\begin{array}{l}-0.004 \\
(0.004)\end{array}$ & $\begin{array}{c}0.002 \\
(0.003)\end{array}$ & $\begin{array}{l}-0.000 \\
(0.003)\end{array}$ & $\begin{array}{c}0.002 \\
(0.002)\end{array}$ \\
\hline $\mathrm{N}$ & 12,000 & 12,000 & 12,000 & 12,000 \\
\hline \multicolumn{5}{|l|}{ Specification II } \\
\hline Workers' Cognition & $\begin{array}{l}-0.003 \\
(0.006)\end{array}$ & $\begin{array}{l}0.010^{* *} \\
(0.004)\end{array}$ & $\begin{array}{l}-0.007 \\
(0.004)\end{array}$ & $\begin{array}{l}-0.000 \\
(0.002)\end{array}$ \\
\hline Workers’ Psychomotor Ability & $\begin{array}{l}-0.021 * * * \\
(0.005)\end{array}$ & $\begin{array}{c}0.006 \\
(0.004)\end{array}$ & $\begin{array}{l}0.015 * * * \\
(0.004)\end{array}$ & $\begin{array}{c}0.001 \\
(0.002)\end{array}$ \\
\hline Workers’ Physical Ability & $\begin{array}{l}-0.024 * * * \\
(0.006)\end{array}$ & $\begin{array}{c}0.007^{*} \\
(0.004)\end{array}$ & $\begin{array}{l}0.018 * * * \\
(0.004)\end{array}$ & $\begin{array}{l}-0.000 \\
(0.002)\end{array}$ \\
\hline Workers’ Eyesight & $\begin{array}{l}-0.023 * * * \\
(0.005)\end{array}$ & $\begin{array}{c}0.007^{*} \\
(0.004)\end{array}$ & $\begin{array}{l}0.014 * * * \\
(0.004)\end{array}$ & $\begin{array}{c}0.001 \\
(0.002)\end{array}$ \\
\hline Workers' Sensory Perception & $\begin{array}{l}-0.017 * * * \\
(0.005)\end{array}$ & $\begin{array}{l}0.010^{* * *} \\
(0.004)\end{array}$ & $\begin{array}{l}0.007 * \\
(0.004)\end{array}$ & $\begin{array}{c}0.001 \\
(0.002)\end{array}$ \\
\hline Required Cognition & $\begin{array}{c}0.000 \\
(0.006)\end{array}$ & $\begin{array}{l}0.009 * * \\
(0.004)\end{array}$ & $\begin{array}{l}-0.009 * \\
(0.004)\end{array}$ & $\begin{array}{l}-0.001 \\
(0.003)\end{array}$ \\
\hline Required Social Skills & $\begin{array}{c}0.004 \\
(0.005)\end{array}$ & $\begin{array}{c}0.006^{*} \\
(0.004)\end{array}$ & $\begin{array}{l}-0.009 * * \\
(0.004)\end{array}$ & $\begin{array}{l}-0.001 \\
(0.002)\end{array}$ \\
\hline Required Experience & $\begin{array}{l}-0.007 \\
(0.005) \\
\end{array}$ & $\begin{array}{c}0.001 \\
(0.003) \\
\end{array}$ & $\begin{array}{c}0.002 \\
(0.004) \\
\end{array}$ & $\begin{array}{c}0.003 \\
(0.002) \\
\end{array}$ \\
\hline $\bar{N}$ & 8991 & 8991 & 8991 & 8991 \\
\hline
\end{tabular}

Specification I includes: gender, age, indicators for age above 62 and 65, education, marital status, age difference with the spouse, indicator for whether the spouse is working, health status, cognitive test scores (word recall and serial 7), hourly wage, type of employer-sponsored pension plan, indicators for whether the respondent and/or the spouse are covered by employer-provided health insurance, and time fixed effects. Specification II adds to the set of regressors personality traits, measures of risk aversion, and family financial planning horizon. Standard errors are clustered at the individual level and reported in parentheses. ${ }^{* * *}, * *$, and $*$ indicate significance at the $1 \%, 5 \%$, and $10 \%$ level, respectively. 
Table 10: Effect of Objective Job Characteristics on Labor Force Transitions

\begin{tabular}{|c|c|c|c|c|}
\hline \multirow[t]{2}{*}{ Covariate } & \multicolumn{4}{|c|}{ Transition from Full-Time to: } \\
\hline & Full-Time & Part-Time & Retired & $\overline{\text { Unemp/Out of LF }}$ \\
\hline \multicolumn{5}{|l|}{ Specification I } \\
\hline Cognitive Demands & $\begin{array}{l}-0.004 \\
(0.005)\end{array}$ & $\begin{array}{l}0.008 * * * \\
(0.003)\end{array}$ & $\begin{array}{l}-0.003 \\
(0.003)\end{array}$ & $\begin{array}{l}-0.002 \\
(0.002)\end{array}$ \\
\hline Physical Demands & $\begin{array}{l}-0.016^{* * * *} \\
(0.005)\end{array}$ & $\begin{array}{c}0.003 \\
(0.003)\end{array}$ & $\begin{array}{l}0.013^{* * * *} \\
(0.003)\end{array}$ & $\begin{array}{c}0.000 \\
(0.002)\end{array}$ \\
\hline Working with Computer & $\begin{array}{l}0.016^{* * *} \\
(0.005)\end{array}$ & $\begin{array}{l}-0.004 \\
(0.003)\end{array}$ & $\begin{array}{l}-0.011^{* * *} \\
(0.004)\end{array}$ & $\begin{array}{l}-0.001 \\
(0.002)\end{array}$ \\
\hline Working with Equipment & $\begin{array}{l}-0.011^{* * *} \\
(0.004)\end{array}$ & $\begin{array}{c}0.002 \\
(0.003)\end{array}$ & $\begin{array}{l}0.008^{* * *} \\
(0.003)\end{array}$ & $\begin{array}{c}0.001 \\
(0.002)\end{array}$ \\
\hline Interaction with Others & $\begin{array}{c}0.004 \\
(0.004)\end{array}$ & $\begin{array}{l}0.007 * * \\
(0.003)\end{array}$ & $\begin{array}{l}-0.009 * * * \\
(0.003)\end{array}$ & $\begin{array}{l}-0.002 \\
(0.002)\end{array}$ \\
\hline Responsibility & $\begin{array}{l}-0.009 * * \\
(0.004)\end{array}$ & $\begin{array}{l}0.011^{* * *} \\
(0.003)\end{array}$ & $\begin{array}{c}0.000 \\
(0.003)\end{array}$ & $\begin{array}{l}-0.003 \\
(0.002)\end{array}$ \\
\hline Difficulty/Stress & $\begin{array}{l}-0.005 \\
(0.004)\end{array}$ & $\begin{array}{c}0.000 \\
(0.003)\end{array}$ & $\begin{array}{c}0.003 \\
(0.003)\end{array}$ & $\begin{array}{c}0.002 \\
(0.002)\end{array}$ \\
\hline $\mathrm{N}$ & 12,000 & 12,000 & 12,000 & 12,000 \\
\hline \multicolumn{5}{|l|}{ Specification II } \\
\hline Cognitive Demands & $\begin{array}{l}-0.006 \\
(0.006)\end{array}$ & $\begin{array}{c}0.009 * * \\
(0.004)\end{array}$ & $\begin{array}{l}-0.002 \\
(0.004)\end{array}$ & $\begin{array}{c}0.000 \\
(0.002)\end{array}$ \\
\hline Physical Demands & $\begin{array}{l}-0.020^{* * *} \\
(0.006)\end{array}$ & $\begin{array}{c}0.002 \\
(0.004)\end{array}$ & $\begin{array}{l}0.016^{* * *} \\
(0.004)\end{array}$ & $\begin{array}{c}0.002 \\
(0.002)\end{array}$ \\
\hline Working with Computer & $\begin{array}{l}0.017^{* * * *} \\
(0.006)\end{array}$ & $\begin{array}{l}-0.002 \\
(0.004)\end{array}$ & $\begin{array}{l}-0.013^{* * *} \\
(0.004)\end{array}$ & $\begin{array}{l}-0.001 \\
(0.003)\end{array}$ \\
\hline Working with Equipment & $\begin{array}{l}-0.017^{* * *} \\
(0.005)\end{array}$ & $\begin{array}{c}0.003 \\
(0.004)\end{array}$ & $\begin{array}{l}0.012^{* * *} \\
(0.004)\end{array}$ & $\begin{array}{c}0.003 \\
(0.002)\end{array}$ \\
\hline Interaction with Others & $\begin{array}{c}0.003 \\
(0.005)\end{array}$ & $\begin{array}{c}0.007^{* *} \\
(0.003)\end{array}$ & $\begin{array}{l}-0.008^{* *} \\
(0.004)\end{array}$ & $\begin{array}{l}-0.001 \\
(0.002)\end{array}$ \\
\hline Responsibility & $\begin{array}{l}-0.013^{* * *} \\
(0.005)\end{array}$ & $\begin{array}{l}0.011^{* * * *} \\
(0.003)\end{array}$ & $\begin{array}{c}0.003 \\
(0.004)\end{array}$ & $\begin{array}{l}-0.001 \\
(0.002)\end{array}$ \\
\hline Difficulty/Stress & $\begin{array}{l}-0.006 \\
(0.005)\end{array}$ & $\begin{array}{l}-0.001 \\
(0.004)\end{array}$ & $\begin{array}{c}0.004 \\
(0.004)\end{array}$ & $\begin{array}{c}0.002 \\
(0.002)\end{array}$ \\
\hline $\mathrm{N}$ & 8991 & 8991 & 8991 & 8991 \\
\hline
\end{tabular}

Specification I includes: gender, age, indicators for age above 62 and 65, education, marital status, age difference with the spouse, indicator for whether the spouse is working, health status, cognitive test scores (word recall and serial 7), hourly wage, type of employer-sponsored pension plan, indicators for whether the respondent and/or the spouse are covered by employer-provided health insurance, and time fixed effects. Specification II adds to the set of regressors personality traits, measures of risk aversion, and family financial planning horizon. Standard errors are clustered at the individual level and reported in parentheses. ${ }^{* * *},{ }^{* *}$, and $*$ indicate significance at the $1 \%, 5 \%$, and $10 \%$ level, respectively. 
correlation coefficient of -0.86). It decreases the probability of remaining in full-time and increases the probability of retirement. Average workers' eyesight is highly correlated with psychomotor and physical ability. A one standard deviation increase in average workers' eyesight is associated with a two-percentage point decrease in the likelihood of remaining fulltime and with a 0.7- and 1.2-percentage point increase in the likelihoods of moving to part-time and to retirement, respectively. The self-reported assessment of the extent to which good eyesight is important for the job acts in a very similar way, although the corresponding coefficients are somewhat smaller and less precisely estimated.

A one standard deviation increase in the "objective" level of social interaction decreases the likelihood of retirement by nearly one percentage point, while increasing the likelihood of moving to part-time by 0.6 percentage points and the one of remaining full-time by 0.4 percentage points (although the latter effect is not statistically significant). On the other hand, the self-reported index of required social skills on the job does not exhibit a significant relationship with labor-force transitions. Perceived task difficulty and job-related stress make individuals less likely to stay employed full-time and more likely to retire altogether. The "objective" degree of on-the-job responsibility instead increases the probability of moving to part-time, but does not affect the transition into complete retirement. Cognitive demands are only available in the O*NET. We estimate that higher levels of required cognitive ability make individuals more likely to move to part-time and less-likely to retire.

As shown in Tables 8-11, these patterns are robust to different specifications (and sample sizes), including those where comparable "subjective" and "objective" measures of a particular job attribute are both used as explanatory variables. In this particular case, the latter typically exhibit larger and more precisely estimated effects. The estimated correlation between selfreported and objective physical demands is about 0.5 . When they are both used as explanatory variables, they retain their effects, with the former affecting the decision to move to part-time and the latter transitions into retirement. The correlation coefficient between subjective and objective measures of eyesight is nearly zero. When both measures of eyesight are included on the right-hand-side of the regression equation only the objective measure is associated with employment transitions. Subjective and objective measures of computer use are strongly and positively correlated (with a coefficient of 0.56 ) and both contribute to explain labor-force transitions. 
Table 11: Effect of Self-Reported and Objective Job Characteristics on Labor Force Transitions

\begin{tabular}{|c|c|c|c|c|}
\hline \multirow[t]{2}{*}{ Covariate } & \multicolumn{4}{|c|}{ Transition from Full-Time to: } \\
\hline & Full-Time & Part-Time & Retired & Unemp/Out of LF \\
\hline HRS Physical Effort & $\begin{array}{l}-0.007 \\
(0.005)\end{array}$ & $\begin{array}{l}0.007 * * \\
(0.004)\end{array}$ & $\begin{array}{c}0.001 \\
(0.004)\end{array}$ & $\begin{array}{l}-0.001 \\
(0.002)\end{array}$ \\
\hline O*NET Psychomotor Ability & $\begin{array}{l}-0.019 * * * \\
(0.006)\end{array}$ & $\begin{array}{c}0.003 \\
(0.004)\end{array}$ & $\begin{array}{l}0.014^{* * *} \\
(0.004)\end{array}$ & $\begin{array}{c}0.001 \\
(0.002)\end{array}$ \\
\hline HRS Physical Effort & $\begin{array}{l}-0.005 \\
(0.005)\end{array}$ & $\begin{array}{c}0.007 * * \\
(0.004)\end{array}$ & $\begin{array}{l}-0.001 \\
(0.004)\end{array}$ & $\begin{array}{l}-0.001 \\
(0.002)\end{array}$ \\
\hline O*NET Physical Ability & $\begin{array}{l}-0.022^{* * *} \\
(0.006)\end{array}$ & $\begin{array}{c}0.004 \\
(0.004)\end{array}$ & $\begin{array}{l}0.018^{* * * *} \\
(0.004)\end{array}$ & $\begin{array}{c}0.000 \\
(0.002)\end{array}$ \\
\hline HRS Physical Effort & $\begin{array}{l}-0.007 \\
(0.005)\end{array}$ & $\begin{array}{l}0.009^{* *} \\
(0.004)\end{array}$ & $\begin{array}{c}0.000 \\
(0.004)\end{array}$ & $\begin{array}{l}-0.002 \\
(0.002)\end{array}$ \\
\hline O*NET Physical Demands & $\begin{array}{l}-0.018^{* * *} \\
(0.006)\end{array}$ & $\begin{array}{l}-0.001 \\
(0.004)\end{array}$ & $\begin{array}{l}0.016^{* * * *} \\
(0.004)\end{array}$ & $\begin{array}{c}0.002 \\
(0.003)\end{array}$ \\
\hline HRS Good Eyesight & $\begin{array}{l}-0.004 \\
(0.005)\end{array}$ & $\begin{array}{l}-0.003 \\
(0.003)\end{array}$ & $\begin{array}{c}0.006 \\
(0.004)\end{array}$ & $\begin{array}{c}0.001 \\
(0.002)\end{array}$ \\
\hline O*NET Eyesight & $\begin{array}{l}-0.023^{* * *} \\
(0.005)\end{array}$ & $\begin{array}{c}0.007^{*} \\
(0.004)\end{array}$ & $\begin{array}{l}0.014^{* * * *} \\
(0.004)\end{array}$ & $\begin{array}{c}0.001 \\
(0.002)\end{array}$ \\
\hline HRS Intense Concentration & $\begin{array}{l}-0.002 \\
(0.005)\end{array}$ & $\begin{array}{l}-0.001 \\
(0.003)\end{array}$ & $\begin{array}{c}0.002 \\
(0.004)\end{array}$ & $\begin{array}{c}0.001 \\
(0.002)\end{array}$ \\
\hline O*NET Sensory Perception & $\begin{array}{l}-0.017 * * * \\
(0.005)\end{array}$ & $\begin{array}{l}0.010^{* * * *} \\
(0.004)\end{array}$ & $\begin{array}{c}0.007^{*} \\
(0.004)\end{array}$ & $\begin{array}{c}0.000 \\
(0.002)\end{array}$ \\
\hline HRS Use of Computer & $\begin{array}{c}0.011^{*} \\
(0.006)\end{array}$ & $\begin{array}{l}-0.012^{* * *} \\
(0.004)\end{array}$ & $\begin{array}{l}-0.002 \\
(0.004)\end{array}$ & $\begin{array}{c}0.003 \\
(0.002)\end{array}$ \\
\hline O*NET Working with Computer & $\begin{array}{c}0.012 * \\
(0.007)\end{array}$ & $\begin{array}{c}0.003 \\
(0.005)\end{array}$ & $\begin{array}{l}-0.013^{* * *} \\
(0.005)\end{array}$ & $\begin{array}{l}-0.003 \\
(0.003)\end{array}$ \\
\hline HRS People Skills & $\begin{array}{l}-0.001 \\
(0.005)\end{array}$ & $\begin{array}{c}0.003 \\
(0.004)\end{array}$ & $\begin{array}{c}0.002 \\
(0.004)\end{array}$ & $\begin{array}{l}-0.004 * \\
(0.002)\end{array}$ \\
\hline O*NET Social Skills & $\begin{array}{c}0.004 \\
(0.005)\end{array}$ & $\begin{array}{c}0.006 \\
(0.004)\end{array}$ & $\begin{array}{l}-0.010^{* *} \\
(0.004)\end{array}$ & $\begin{array}{l}-0.000 \\
(0.002)\end{array}$ \\
\hline HRS People Skills & $\begin{array}{l}-0.001 \\
(0.005)\end{array}$ & $\begin{array}{c}0.003 \\
(0.004)\end{array}$ & $\begin{array}{c}0.002 \\
(0.004)\end{array}$ & $\begin{array}{l}-0.004 * \\
(0.002)\end{array}$ \\
\hline O*NET Interaction with Others & $\begin{array}{c}0.003 \\
(0.005)\end{array}$ & $\begin{array}{c}0.006^{*} \\
(0.003)\end{array}$ & $\begin{array}{l}-0.009 * * \\
(0.004)\end{array}$ & $\begin{array}{l}-0.000 \\
(0.002)\end{array}$ \\
\hline HRS Difficulty/Stress & $\begin{array}{l}-0.011^{* *} \\
(0.005)\end{array}$ & $\begin{array}{l}-0.000 \\
(0.003)\end{array}$ & $\begin{array}{l}0.012^{* * *} \\
(0.004)\end{array}$ & $\begin{array}{l}-0.001 \\
(0.002)\end{array}$ \\
\hline O*NET Responsibility & $\begin{array}{l}-0.013^{* *} \\
(0.005)\end{array}$ & $\begin{array}{l}0.015^{* * *} \\
(0.004)\end{array}$ & $\begin{array}{c}0.001 \\
(0.004)\end{array}$ & $\begin{array}{l}-0.002 \\
(0.002)\end{array}$ \\
\hline O*NET Difficulty/Stress & $\begin{array}{c}0.001 \\
(0.006)\end{array}$ & $\begin{array}{l}-0.008^{*} \\
(0.004)\end{array}$ & $\begin{array}{c}0.004 \\
(0.004)\end{array}$ & $\begin{array}{c}0.003 \\
(0.002)\end{array}$ \\
\hline
\end{tabular}

All regressions use Specification II (see notes to Tables 8-10). Each specification includes HRS and O*NET measures of a comparable job attribute. Standard errors are clustered at the individual level and reported in parentheses. ***, **, and * indicate significance at the $1 \%, 5 \%$, and $10 \%$ level, respectively. 
Finally, it is worth noting that the HRS asks respondents whether they feel discriminated on the job or pressured to retire because of their age. A one standard deviation increase in perceived age discrimination decreases the likelihood of remaining in full-time work by about 1.5 percentage points and increases the likelihood of retirement by 1.3 percentage points. An objective measure of age discrimination is not yet available in the O*NET.

\section{Results: Retirement Intentions}

We now turn to an investigation of the extent to which nonmonetary job characteristics influence retirement plans (time to planned retirement) and subjective probabilities of working full-time after age 62 and 65 . The results of this analysis turn out to be in line with those for labor-force transitions described above.

The estimated coefficients in Table 12a show that female workers intend to retire earlier than their male counterparts. On average, women's subjective probability of working full-time after age 62 and 65 is about five percentage points lower than men's. There is a clear education gradient of the time until planned retirement and probabilities of working at older ages as they both increase substantially with educational attainment. Being in a couple increases time until planned retirement by more than half a year and the probabilities of working full-time after age 62 and 65 by about 7.5 percentage points. Poor health reduces time to planned retirement by about six months and reduces the probability to work past 62 or past 65 by about five percentage points. Not surprisingly, compensation and fringe benefits are important determinants of retirement intentions. A higher wage rate is associated with a shorter time until planned retirement and lower subjective probabilities of working at older ages. The financial incentives of defined benefit pension plans make individuals plan for an earlier exit from the labor force, other things being equal. Workers covered by employer-sponsored health insurance report a significantly lower probability of continuing in full-time employment after ages 62 and 65 . The incremental effect of having the spouse covered by the same employer-sponsored health insurance is, instead, negligible.

Table 12b shows that individual traits are not strongly correlated with retirement intentions. Openness to experience increases the subjective probabilities of working after age 62 and 65 by nearly 3.5 and five percentage points, respectively. High risk aversion is associated with a shorter 
Table 12a: Retirement Intentions - Controls

\begin{tabular}{|c|c|c|c|}
\hline Covariate & $\begin{array}{c}\text { Years until } \\
\text { Planned Retirement Age }\end{array}$ & $\begin{array}{c}\text { Probability of } \\
\text { FT Work after } 62\end{array}$ & $\begin{array}{c}\text { Probability of } \\
\text { FT Work after } 65\end{array}$ \\
\hline Female & $\begin{array}{l}-0.607^{* * *} \\
(0.121)\end{array}$ & $\begin{array}{l}-5.143^{* * *} \\
(0.980)\end{array}$ & $\begin{array}{l}-4.291 * * * \\
(0.916)\end{array}$ \\
\hline Age & $\begin{array}{l}-0.637^{* * *} \\
(0.016)\end{array}$ & $\begin{array}{l}1.079^{* * *} \\
(0.119)\end{array}$ & $\begin{array}{l}0.424^{* * *} \\
(0.111)\end{array}$ \\
\hline Spouse Age Diff. & $\begin{array}{l}0.028^{* * *} \\
(0.011)\end{array}$ & $\begin{array}{l}0.262^{* * *} \\
(0.087)\end{array}$ & $\begin{array}{l}0.311^{* * *} \\
(0.086)\end{array}$ \\
\hline Age $\geq 62$ & $\begin{array}{l}-0.143 \\
(0.146)\end{array}$ & & $\begin{array}{l}6.149 * * * \\
(1.137)\end{array}$ \\
\hline Age $\geq 65$ & $\begin{array}{l}3.425^{* * *} \\
(0.166)\end{array}$ & & \\
\hline High School & $\begin{array}{c}0.199 \\
(0.146)\end{array}$ & $\begin{array}{l}3.625^{* * *} \\
(1.406)\end{array}$ & $\begin{array}{l}2.837 * * \\
(1.247)\end{array}$ \\
\hline Some College & $\begin{array}{l}0.617^{* * * *} \\
(0.153)\end{array}$ & $\begin{array}{l}6.029 * * * \\
(1.421)\end{array}$ & $\begin{array}{l}6.137 * * * \\
(1.283)\end{array}$ \\
\hline College and Above & $\begin{array}{l}1.053^{* * *} \\
(0.170)\end{array}$ & $\begin{array}{l}8.000^{* * *} \\
(1.567)\end{array}$ & $\begin{array}{l}7.686^{* * *} \\
(1.410)\end{array}$ \\
\hline In a Couple & $\begin{array}{l}-0.742^{* * *} \\
(0.138)\end{array}$ & $\begin{array}{l}-7.453^{* * * *} \\
(1.269)\end{array}$ & $\begin{array}{l}-7.723^{* * * *} \\
(1.160)\end{array}$ \\
\hline Spouse Working & $\begin{array}{c}0.212^{*} \\
(0.116)\end{array}$ & $\begin{array}{c}1.402 \\
(1.037)\end{array}$ & $\begin{array}{c}0.689 \\
(0.918)\end{array}$ \\
\hline Poor Health & $\begin{array}{l}-0.547^{* * *} \\
(0.122)\end{array}$ & $\begin{array}{l}-5.105^{* * *} \\
(1.060)\end{array}$ & $\begin{array}{l}-4.376^{* * *} \\
(0.953)\end{array}$ \\
\hline Low Word Recall Score & $\begin{array}{c}0.116 \\
(0.093)\end{array}$ & $\begin{array}{l}2.267^{* * *} \\
(0.750)\end{array}$ & $\begin{array}{l}2.024 * * * \\
(0.674)\end{array}$ \\
\hline Low Serial 7 Score & $\begin{array}{c}0.114 \\
(0.089)\end{array}$ & $\begin{array}{l}2.190^{* * * *} \\
(0.752)\end{array}$ & $\begin{array}{c}0.294 \\
(0.674)\end{array}$ \\
\hline Hourly Wage & $\begin{array}{l}-0.825^{* * * *} \\
(0.098)\end{array}$ & $\begin{array}{l}-0.892 \\
(0.789)\end{array}$ & $\begin{array}{l}-1.921 * * * \\
(0.722)\end{array}$ \\
\hline DB Pension & $\begin{array}{l}-0.955^{* * *} \\
(0.234)\end{array}$ & $\begin{array}{l}-7.081^{* * * *} \\
(2.445)\end{array}$ & $\begin{array}{l}-8.350^{* * *} \\
(2.119)\end{array}$ \\
\hline DC Pension & $\begin{array}{c}0.032 \\
(0.224)\end{array}$ & $\begin{array}{c}2.004 \\
(2.346)\end{array}$ & $\begin{array}{l}-1.211 \\
(2.040)\end{array}$ \\
\hline DB/DC Pension & $\begin{array}{l}-0.553^{*} \\
(0.301)\end{array}$ & $\begin{array}{l}-2.013 \\
(2.956)\end{array}$ & $\begin{array}{l}-7.420^{* * *} \\
(2.588)\end{array}$ \\
\hline Missing Pension Info & $\begin{array}{l}0.742^{* * *} \\
(0.209)\end{array}$ & $\begin{array}{l}-1.994 \\
(2.232)\end{array}$ & $\begin{array}{l}-1.498 \\
(1.946)\end{array}$ \\
\hline Emp. Health Ins. (R) & $\begin{array}{l}-0.205 \\
(0.130)\end{array}$ & $\begin{array}{l}7.221^{* * * *} \\
(1.090)\end{array}$ & $\begin{array}{l}6.435^{* * * *} \\
(0.958)\end{array}$ \\
\hline Emp. Health Ins. (S) & $\begin{array}{c}0.176 \\
(0.122)\end{array}$ & $\begin{array}{l}1.830^{*} \\
(1.081)\end{array}$ & $\begin{array}{c}0.817 \\
(0.969)\end{array}$ \\
\hline Time Fixed-Effects & $\mathrm{Y}$ & $\mathrm{Y}$ & $\mathrm{Y}$ \\
\hline $\mathrm{N}$ & 9,921 & 12,199 & 14,116 \\
\hline
\end{tabular}


Table 12b: Retirement Intentions - Controls (cont.)

\begin{tabular}{l|ccc}
\hline \multicolumn{1}{c|}{ Covariate } & $\begin{array}{c}\text { Years until } \\
\text { Planned Retirement Age }\end{array}$ & $\begin{array}{c}\text { Probability of } \\
\text { FT Work after 62 }\end{array}$ & $\begin{array}{c}\text { Probability of } \\
\text { FT Work after 65 }\end{array}$ \\
\hline Openness to & 0.156 & $3.403^{* *}$ & $4.791^{* * *}$ \\
Conscientiousness & $(0.144)$ & $(1.367)$ & $(1.237)$ \\
Extraversion & -0.136 & -1.300 & -0.595 \\
& $(0.155)$ & $(1.520)$ & $(1.378)$ \\
Agreeableness & 0.188 & -1.335 & -1.208 \\
Neuroticism & $(0.141)$ & $(1.357)$ & $(1.211)$ \\
& -0.109 & 1.736 & -0.731 \\
High Risk Aversion & $(0.170)$ & $(1.532)$ & $(1.379)$ \\
& 0.033 & -0.266 & 0.777 \\
Long Planning & $(0.103)$ & $(1.015)$ & $(0.887)$ \\
& $-0.204 *$ & -1.372 & $-1.594 *$ \\
$\mathrm{~N}$ & $(0.114)$ & $(1.033)$ & $1.925)$ \\
\hline All & $0.372^{* * *}$ & $1.844 *$ & $(0.865)$ \\
\hline
\end{tabular}

All the controls in Table 12a are included in Table 12b. Differences in sample size are due to missing individualspecific traits. Standard errors are clustered at the individual level and reported in parentheses. ***, **, and * indicate significance at the $1 \%, 5 \%$, and $10 \%$ level, respectively.

time until planned retirement and lower chances of working past ages 62 and 65. Finally, having a financial planning horizon of at least five years increases the time until expected retirement age, while having only a minor effect on the subjective probabilities of remaining in full-time employment after ages 62 and 65.

In Table 13 we estimate that a one standard deviation increase in perceived physical effort shortens time until planned retirement by about two months and has no significant effect on the probabilities of working at older ages. In Tables 14 and 15, we find that a one standard deviation increase in the objective level of physical demands decreases planned retirement age by about a quarter of a year. Similarly, it decreases the subjective probability of working fulltime after age 62 by 2.5 percentage points, a $4.5 \%$ change relative to the observed average of $53 \%$. It also decreases the probability of working full-time after age 65 by 3 percentage points, a $9 \%$ change relative to the observed average of $34 \%$. All the measures that correlate positively with physical demands, such as eyesight and use of equipment, operate in the same direction. 
Table 13: Effect of Self-Reported Nonmonetary Job Characteristics on Retirement Intentions

\begin{tabular}{|c|c|c|c|}
\hline Covariate & $\begin{array}{c}\text { Years until } \\
\text { Planned Retirement Age }\end{array}$ & $\begin{array}{c}\text { Probability of } \\
\text { FT Work after } 62\end{array}$ & $\begin{array}{c}\text { Probability of } \\
\text { FT Work after } 65\end{array}$ \\
\hline \multicolumn{4}{|l|}{ Specification I } \\
\hline Physical Effort & $\begin{array}{l}-0.164^{* * *} \\
(0.052)\end{array}$ & $\begin{array}{l}-0.004 \\
(0.436)\end{array}$ & $\begin{array}{c}0.650^{*} \\
(0.364)\end{array}$ \\
\hline Good Eyesight & $\begin{array}{l}-0.066 \\
(0.050)\end{array}$ & $\begin{array}{c}0.396 \\
(0.393)\end{array}$ & $\begin{array}{c}0.006^{*} \\
(0.003)\end{array}$ \\
\hline Intense Concentration & $\begin{array}{l}-0.006 \\
(0.047)\end{array}$ & $\begin{array}{l}1.866^{* * *} \\
(0.413)\end{array}$ & $\begin{array}{l}1.551^{* * *} \\
(0.363)\end{array}$ \\
\hline People Skills & $\begin{array}{c}0.078^{*} \\
(0.046)\end{array}$ & $\begin{array}{c}0.487 \\
(0.430)\end{array}$ & $\begin{array}{l}1.119^{* * *} \\
(0.377)\end{array}$ \\
\hline Use of Computer & $\begin{array}{c}0.139 * * \\
(0.055)\end{array}$ & $\begin{array}{l}2.736^{* * *} \\
(0.469)\end{array}$ & $\begin{array}{l}2.764^{* * *} \\
(0.422)\end{array}$ \\
\hline$\overline{\text { Difficulty/Stress }}$ & $\begin{array}{l}-0.170^{* * *} \\
(0.049)\end{array}$ & $\begin{array}{c}0.901^{* *} \\
(0.401)\end{array}$ & $\begin{array}{c}0.424 \\
(0.364)\end{array}$ \\
\hline Age Discrimination & $\begin{array}{l}-0.276^{* * *} \\
(0.045)\end{array}$ & $\begin{array}{l}-2.904^{* * *} \\
(0.362)\end{array}$ & $\begin{array}{l}-2.405^{* * *} \\
(0.333)\end{array}$ \\
\hline$\overline{\mathrm{N}}$ & 9,921 & 12,199 & 14,116 \\
\hline \multicolumn{4}{|l|}{ Specification II } \\
\hline Physical Effort & $\begin{array}{l}-0.161^{* * *} \\
(0.059)\end{array}$ & $\begin{array}{c}0.005 \\
(0.548)\end{array}$ & $\begin{array}{c}0.683 \\
(0.452)\end{array}$ \\
\hline Good Eyesight & $\begin{array}{l}-0.063 \\
(0.058)\end{array}$ & $\begin{array}{c}0.389 \\
(0.504)\end{array}$ & $\begin{array}{c}0.007^{*} \\
(0.004)\end{array}$ \\
\hline Intense Concentration & $\begin{array}{l}-0.026 \\
(0.055)\end{array}$ & $\begin{array}{l}1.816^{* * * *} \\
(0.512)\end{array}$ & $\begin{array}{l}1.551^{* * *} \\
(0.363)\end{array}$ \\
\hline People Skills & $\begin{array}{c}0.105^{* *} \\
(0.052)\end{array}$ & $\begin{array}{c}0.197 \\
(0.541)\end{array}$ & $\begin{array}{c}0.969 * * \\
(0.467)\end{array}$ \\
\hline Use of Computer & $\begin{array}{c}0.077 \\
(0.062)\end{array}$ & $\begin{array}{l}2.245^{* * *} \\
(0.579)\end{array}$ & $\begin{array}{l}2.565^{* * *} \\
(0.509)\end{array}$ \\
\hline Difficulty/Stress & $\begin{array}{l}-0.176^{* * *} \\
(0.056)\end{array}$ & $\begin{array}{l}1.010^{* *} \\
(0.496)\end{array}$ & $\begin{array}{c}0.294 \\
(0.442)\end{array}$ \\
\hline Age Discrimination & $\begin{array}{l}-0.224^{* * *} \\
(0.053)\end{array}$ & $\begin{array}{l}-2.723^{* * *} \\
(0.454)\end{array}$ & $\begin{array}{l}-2.377^{* * *} \\
(0.413)\end{array}$ \\
\hline$\overline{\mathrm{N}}$ & 7,445 & 8,540 & 10,174 \\
\hline
\end{tabular}

Specification I includes: gender, age, indicators for age above 62 and 65, education, marital status, age difference with the spouse, indicator for whether the spouse is working, health status, cognitive test scores (word recall and serial 7), hourly wage, type of employer-sponsored pension plan, indicators for whether the respondent and/or the spouse are covered by employer-provided health insurance, and time fixed effects. Specification II adds to the set of regressors personality traits, measures of risk aversion, and family financial planning horizon. Standard errors are clustered at the individual level and reported in parentheses. ${ }^{* * *}, *^{* *}$, and * indicate significance at the $1 \%, 5 \%$, and $10 \%$ level, respectively. 
Table 14: Effect of Objective Workers' Characteristics and Requirements on Retirement Intentions

\begin{tabular}{|c|c|c|c|}
\hline Covariate & $\begin{array}{c}\text { Years until } \\
\text { Planned Retirement Age }\end{array}$ & $\begin{array}{c}\text { Probability of } \\
\text { FT Work after } 62\end{array}$ & $\begin{array}{c}\text { Probability of } \\
\text { FT Work after } 65\end{array}$ \\
\hline \multicolumn{4}{|l|}{ Specification I } \\
\hline Workers’ Cognition & $\begin{array}{l}0.210 * * * \\
(0.058)\end{array}$ & $\begin{array}{l}1.237 * * \\
(0.492)\end{array}$ & $\begin{array}{l}1.420 * * * \\
(0.447)\end{array}$ \\
\hline Workers’ Psychomotor & $\begin{array}{l}-0.211^{* * *} \\
(0.054)\end{array}$ & $\begin{array}{l}-1.887 * * * \\
(0.475)\end{array}$ & $\begin{array}{l}-2.438 * * * \\
(0.432)\end{array}$ \\
\hline Workers’ Physical Ability & $\begin{array}{l}-0.215 * * * \\
(0.066)\end{array}$ & $\begin{array}{l}-2.689 * * * \\
(0.626)\end{array}$ & $\begin{array}{l}-2.607 * * * \\
(0.547)\end{array}$ \\
\hline Workers’ Eyesight & $\begin{array}{l}-0.141 * * * \\
(0.054)\end{array}$ & $\begin{array}{l}-1.916 * * * \\
(0.470)\end{array}$ & $\begin{array}{l}-2.110 * * * \\
(0.423)\end{array}$ \\
\hline Workers' Sensory Perception & $\begin{array}{c}0.010 \\
(0.052)\end{array}$ & $\begin{array}{l}-0.521 \\
(0.445)\end{array}$ & $\begin{array}{l}-0.607 \\
(0.408)\end{array}$ \\
\hline Required Cognition & $\begin{array}{l}0.219 * * * \\
(0.059)\end{array}$ & $\begin{array}{l}1.339 * * * \\
(0.503)\end{array}$ & $\begin{array}{l}1.646^{* * *} \\
(0.457)\end{array}$ \\
\hline Required Social Skills & $\begin{array}{l}0.209 * * * \\
(0.054) \\
\end{array}$ & $\begin{array}{l}1.108^{* *} \\
(0.468) \\
\end{array}$ & $\begin{array}{l}1.728 * * * \\
(0.426)\end{array}$ \\
\hline Required Experience & $\begin{array}{c}0.069 \\
(0.056)\end{array}$ & $\begin{array}{c}0.526 \\
(0.467)\end{array}$ & $\begin{array}{c}0.619 \\
(0.423)\end{array}$ \\
\hline $\mathrm{N}$ & 9,921 & 12,199 & 14,116 \\
\hline \multicolumn{4}{|l|}{ Specification II } \\
\hline Workers' Cognition & $\begin{array}{l}0.154 * * \\
(0.066)\end{array}$ & $\begin{array}{c}0.721 \\
(0.624) \\
\end{array}$ & $\begin{array}{c}0.723 \\
(0.552) \\
\end{array}$ \\
\hline Workers’ Psychomotor & $\begin{array}{l}-0.210 * * * \\
(0.062)\end{array}$ & $\begin{array}{l}-2.027 * * * \\
(0.609)\end{array}$ & $\begin{array}{l}-2.242 * * * \\
(0.544)\end{array}$ \\
\hline Workers’ Physical Ability & $\begin{array}{l}-0.215^{* * *} \\
(0.066)\end{array}$ & $\begin{array}{l}-2.689 * * * \\
(0.626)\end{array}$ & $\begin{array}{l}-2.607 * * * \\
(0.547)\end{array}$ \\
\hline Workers’ Eyesight & $\begin{array}{l}-0.173 * * * \\
(0.062)\end{array}$ & $\begin{array}{l}-2.234 * * * \\
(0.612)\end{array}$ & $\begin{array}{l}-2.261 * * * \\
(0.540)\end{array}$ \\
\hline Workers' Sensory Perception & $\begin{array}{l}-0.027 \\
(0.061)\end{array}$ & $\begin{array}{l}-1.130 * \\
(0.577)\end{array}$ & $\begin{array}{l}-1.036 * * \\
(0.517)\end{array}$ \\
\hline Required Cognition & $\begin{array}{l}0.183 * * * \\
(0.067)\end{array}$ & $\begin{array}{c}0.905 \\
(0.644)\end{array}$ & $\begin{array}{l}1.018 * \\
(0.569)\end{array}$ \\
\hline Required Social Skills & $\begin{array}{l}0.183^{* * *} \\
(0.062)\end{array}$ & $\begin{array}{c}0.752 \\
(0.598)\end{array}$ & $\begin{array}{l}1.152^{* *} \\
(0.531)\end{array}$ \\
\hline Required Experience & $\begin{array}{l}-0.018 \\
(0.064) \\
\end{array}$ & $\begin{array}{c}0.201 \\
(0.591) \\
\end{array}$ & $\begin{array}{c}0.022 \\
(0.521) \\
\end{array}$ \\
\hline $\mathrm{N}$ & 7445 & 8540 & 10174 \\
\hline
\end{tabular}

Specification I includes: gender, age, indicators for age above 62 and 65, education, marital status, age difference with the spouse, indicator for whether the spouse is working, health status, cognitive test scores (word recall and serial 7), hourly wage, type of employer-sponsored pension plan, indicators for whether the respondent and/or the spouse are covered by employer-provided health insurance, and time fixed effects. Specification II adds to the set of regressors personality traits, measures of risk aversion and family financial planning horizon. Standard errors are clustered at the individual level and reported in parentheses. ${ }^{* *},{ }^{* *}$, and * indicate significance at the $1 \%, 5 \%$, and $10 \%$ level, respectively. 
Only the $\mathrm{O} *$ NET measure of computer use shows a positive and robust effect on time until planned retirement. In contrast, both the objective and subjective computer use variables exhibit a positive relationship with the probabilities of working full-time after ages 62 and 65 . Perceived and objective social skills requirements are associated with longer time until planned retirement age, as well as with a higher likelihood of working past age 65. A similar pattern is observed for cognitive demands, although no directly comparable, self-reported measure is available in this case. Individuals who perceive their job as requiring intense concentration also report higher chances of working full-time after ages 62 and 65. Perceived task difficulty and job-related stress shorten time until planned retirement, but increase the self-reported probability of working full-time after age 62. They do not correlate, though, with the subjective probability of working after age 65. A one standard deviation increase in the objective measure of on-the-job responsibility decreases the probabilities of working after ages 62 and 65 by 1.3 and 0.8 percentage points, respectively, but has no significant effect on planned retirement age. The O*NET measure of difficulty/stress is not associated with retirement intentions and working expectations. Finally, a one standard deviation increase in the perception of age discrimination in the workplace is associated with a quarter of a year earlier planned retirement age and lower by 2.5 percentage points subjective probabilities of working full-time after age 62 and 65.

Overall, the estimated effects of nonmonetary job characteristics are stronger and more robust to alternative specifications when measures of job attributes are taken from the O*NET rather than from the HRS. This is consistent with the weak correlation between self-reported job characteristics and expectations about working by other studies using the HRS (e.g., Hurd and McGarry, 1993). The patterns described above persist when subjective and objective measures of comparable job attributes are both used as regressors (Table 16). More precisely, measures of physical demands taken from the $\mathrm{O}^{*} \mathrm{NET}$ are strongly and negatively associated with time from planned retirement and subjective probabilities of working full-time after age 62 and 65. Conditional on such "objective” measures, the effect of self-reported on-the-job physical effort on retirement intentions is smaller and often not statistically different from zero. Both O*NET and HRS measures of computer use are positively related to the subjective probability of working fulltime after age 62 and 65. Only the former, however, correlates with a longer distance from planned retirement. The self-reported measure of intense concentration increases the probabilities of working full-time after age 62 and 65, while the O*NET index of sensory perception has the oppo- 
Table 15: Effect of Objective Job Characteristics on Retirement Intentions

\begin{tabular}{|c|c|c|c|}
\hline Covariate & $\begin{array}{c}\text { Years until } \\
\text { Planned Retirement Age }\end{array}$ & $\begin{array}{c}\text { Probability of } \\
\text { FT Work after } 62\end{array}$ & $\begin{array}{c}\text { Probability of } \\
\text { FT Work after } 65\end{array}$ \\
\hline \multicolumn{4}{|l|}{ Specification I } \\
\hline Cognitive Demands & $\begin{array}{l}0.142^{* *} \\
(0.057)\end{array}$ & $\begin{array}{c}0.824^{*} \\
(0.478)\end{array}$ & $\begin{array}{c}0.800^{*} \\
(0.438)\end{array}$ \\
\hline Physical Demands & $\begin{array}{l}-0.259 * * * \\
(0.058)\end{array}$ & $\begin{array}{l}-2.237^{* * * *} \\
(0.496)\end{array}$ & $\begin{array}{l}-2.823^{* * * *} \\
(0.446)\end{array}$ \\
\hline Working with Computer & $\begin{array}{l}0.257^{* * * *} \\
(0.058)\end{array}$ & $\begin{array}{l}2.615^{* * * *} \\
(0.495)\end{array}$ & $\begin{array}{l}2.498 * * * \\
(0.438)\end{array}$ \\
\hline Working with Equipment & $\begin{array}{l}-0.152^{* * *} \\
(0.053)\end{array}$ & $\begin{array}{l}-0.963^{* *} \\
(0.456)\end{array}$ & $\begin{array}{l}-1.747^{* * *} \\
(0.428)\end{array}$ \\
\hline Interaction with Others & $\begin{array}{l}0.185^{* * *} \\
(0.053)\end{array}$ & $\begin{array}{c}0.824^{*} \\
(0.462)\end{array}$ & $\begin{array}{l}1.494^{* * * *} \\
(0.422)\end{array}$ \\
\hline Responsibility & $\begin{array}{l}-0.017 \\
(0.047)\end{array}$ & $\begin{array}{l}-1.074^{* * *} \\
(0.405)\end{array}$ & $\begin{array}{l}-0.609^{*} \\
(0.370)\end{array}$ \\
\hline Difficulty/Stress & $\begin{array}{l}-0.036 \\
(0.051) \\
\end{array}$ & $\begin{array}{l}-0.337 \\
(0.423) \\
\end{array}$ & $\begin{array}{l}-0.127 \\
(0.383) \\
\end{array}$ \\
\hline$\overline{\mathrm{N}}$ & 9,921 & 12,199 & 14,116 \\
\hline \multicolumn{4}{|l|}{ Specification II } \\
\hline Cognitive Demands & $\begin{array}{c}0.103 \\
(0.066)\end{array}$ & $\begin{array}{c}0.417 \\
(0.604)\end{array}$ & $\begin{array}{c}0.294 \\
(0.540)\end{array}$ \\
\hline Physical Demands & $\begin{array}{l}-0.260^{* * *} \\
(0.067)\end{array}$ & $\begin{array}{l}-2.241^{* * *} \\
(0.642)\end{array}$ & $\begin{array}{l}-2.538^{* * *} \\
(0.564)\end{array}$ \\
\hline Working with Computer & $\begin{array}{l}0.242^{* * *} \\
(0.068)\end{array}$ & $\begin{array}{l}2.419^{* * *} \\
(0.638)\end{array}$ & $\begin{array}{l}2.142^{* * *} \\
(0.547)\end{array}$ \\
\hline Working with Equipment & $\begin{array}{l}-0.205^{* * *} \\
(0.061)\end{array}$ & $\begin{array}{l}-1.272^{* *} \\
(0.595)\end{array}$ & $\begin{array}{l}-1.941 * * * \\
(0.548)\end{array}$ \\
\hline Interaction with Others & $\begin{array}{l}0.157^{* * *} \\
(0.060)\end{array}$ & $\begin{array}{c}0.508 \\
(0.587)\end{array}$ & $\begin{array}{c}0.940^{*} \\
(0.525)\end{array}$ \\
\hline Responsibility & $\begin{array}{l}-0.035 \\
(0.054)\end{array}$ & $\begin{array}{l}-1.351 * * * \\
(0.522)\end{array}$ & $\begin{array}{l}-0.882^{*} \\
(0.466)\end{array}$ \\
\hline$\overline{\text { Difficulty/Stress }}$ & $\begin{array}{l}-0.060 \\
(0.059)\end{array}$ & $\begin{array}{l}0.556 \\
(0.554) \\
\end{array}$ & $\begin{array}{l}-0.283 \\
(0.484)\end{array}$ \\
\hline$\overline{\mathrm{N}}$ & 7,445 & 8,540 & 10,174 \\
\hline
\end{tabular}

Specification I includes: gender, age, indicators for age above 62 and 65, education, marital status, age difference with the spouse, indicator for whether the spouse is working, health status, cognitive test scores (word recall and serial 7), hourly wage, type of employer-sponsored pension plan, indicators for whether the respondent and/or the spouse are covered by employer-provided health insurance, and time fixed effects. Specification II adds to the set of regressors personality traits, measures of risk aversion and family financial planning horizon. Standard errors are clustered at the individual level and reported in parentheses. ${ }^{* * *}$, ${ }^{* *}$, and * indicate significance at the $1 \%, 5 \%$, and $10 \%$ level, respectively. 
Table 16: Effect of Self-Reported and Objective Job Characteristics on Retirement Intentions

\begin{tabular}{|c|c|c|c|}
\hline Covariate & $\begin{array}{c}\text { Years until } \\
\text { Planned Retirement Age }\end{array}$ & $\begin{array}{c}\text { Probability of } \\
\text { FT Work after } 62\end{array}$ & $\begin{array}{c}\text { Probability of } \\
\text { FT Work after } 65\end{array}$ \\
\hline HRS Physical Effort & $\begin{array}{l}-0.114 * \\
(0.062)\end{array}$ & $\begin{array}{c}0.646 \\
(0.570)\end{array}$ & $\begin{array}{r}0.880^{*} \\
(0.517)\end{array}$ \\
\hline O*NET Psychomotor Ability & $\begin{array}{l}-0.173^{* * *} \\
(0.065)\end{array}$ & $\begin{array}{l}-2.259 * * * \\
(0.635)\end{array}$ & $\begin{array}{l}-2.554 * * * \\
(0.567)\end{array}$ \\
\hline HRS Physical Effort & $\begin{array}{l}-0.109^{*} \\
(0.063)\end{array}$ & $\begin{array}{c}0.974^{*} \\
(0.578)\end{array}$ & $\begin{array}{l}1.108^{* *} \\
(0.525)\end{array}$ \\
\hline O*NET Physical Ability & $\begin{array}{l}-0.174^{* *} \\
(0.070)\end{array}$ & $\begin{array}{l}-3.090^{* * *} \\
(0.661)\end{array}$ & $\begin{array}{l}-3.057^{* * *} \\
(0.579)\end{array}$ \\
\hline HRS Physical Effort & $\begin{array}{l}-0.100 \\
(0.062)\end{array}$ & $\begin{array}{c}0.723 \\
(0.573)\end{array}$ & $\begin{array}{c}0.985^{*} \\
(0.521)\end{array}$ \\
\hline O*NET Physical Demands & $\begin{array}{l}-0.223^{* * *} \\
(0.070)\end{array}$ & $\begin{array}{l}-2.531^{* * *} \\
(0.672)\end{array}$ & $\begin{array}{l}-2.928^{* * *} \\
(0.593)\end{array}$ \\
\hline HRS Good Eyesight & $\begin{array}{l}-0.053 \\
(0.058)\end{array}$ & $\begin{array}{c}0.506 \\
(0.504)\end{array}$ & $\begin{array}{c}0.798^{*} \\
(0.452)\end{array}$ \\
\hline O*NET Eyesight & $\begin{array}{l}-0.169 * * * \\
(0.062)\end{array}$ & $\begin{array}{l}-2.268^{* * *} \\
(0.614)\end{array}$ & $\begin{array}{l}-2.313^{* * *} \\
(0.541)\end{array}$ \\
\hline HRS Intense Concentration & $\begin{array}{l}-0.023 \\
(0.055)\end{array}$ & $\begin{array}{l}1.946^{* * * *} \\
(0.514)\end{array}$ & $\begin{array}{l}1.634 * * * \\
(0.442)\end{array}$ \\
\hline O*NET Sensory Perception & $\begin{array}{l}-0.024 \\
(0.062)\end{array}$ & $\begin{array}{l}-1.351^{* *} \\
(0.577)\end{array}$ & $\begin{array}{l}-1.216^{* *} \\
(0.517)\end{array}$ \\
\hline HRS Use of Computer & $\begin{array}{l}-0.009 \\
(0.066)\end{array}$ & $\begin{array}{l}1.646^{* * *} \\
(0.623)\end{array}$ & $\begin{array}{l}2.142^{* * *} \\
(0.551)\end{array}$ \\
\hline O*NET Working with Computer & $\begin{array}{l}0.246^{* * *} \\
(0.073)\end{array}$ & $\begin{array}{l}1.685^{* *} \\
(0.689)\end{array}$ & $\begin{array}{l}1.192^{* *} \\
(0.592)\end{array}$ \\
\hline HRS People Skills & $\begin{array}{c}0.075 \\
(0.052)\end{array}$ & $\begin{array}{c}0.055 \\
(0.546)\end{array}$ & $\begin{array}{c}0.782^{*} \\
(0.472)\end{array}$ \\
\hline O*NET Social Skills & $\begin{array}{l}0.165^{* * *} \\
(0.062)\end{array}$ & $\begin{array}{c}0.739 \\
(0.605)\end{array}$ & $\begin{array}{l}0.979 * \\
(0.539)\end{array}$ \\
\hline HRS People Skills & $\begin{array}{c}0.082 \\
(0.052)\end{array}$ & $\begin{array}{c}0.107 \\
(0.546)\end{array}$ & $\begin{array}{c}0.830^{*} \\
(0.472)\end{array}$ \\
\hline O*NET Interaction with Others & $\begin{array}{l}0.140^{* *} \\
(0.061)\end{array}$ & $\begin{array}{c}0.487 \\
(0.593)\end{array}$ & $\begin{array}{c}0.770 \\
(0.532)\end{array}$ \\
\hline HRS Difficulty/Stress & $\begin{array}{l}-0.174^{* * *} \\
(0.056)\end{array}$ & $\begin{array}{l}1.082^{* *} \\
(0.496)\end{array}$ & $\begin{array}{c}0.339 \\
(0.442)\end{array}$ \\
\hline O*NET Responsibility & $\begin{array}{l}-0.004 \\
(0.060)\end{array}$ & $\begin{array}{l}-1.445^{* *} \\
(0.589)\end{array}$ & $\begin{array}{l}-0.963^{*} \\
(0.525)\end{array}$ \\
\hline O*NET Difficulty/Stress & $\begin{array}{l}-0.054 \\
(0.066)\end{array}$ & $\begin{array}{c}0.094 \\
(0.625)\end{array}$ & $\begin{array}{c}0.158 \\
(0.546) \\
\end{array}$ \\
\hline
\end{tabular}

All regressions use Specification II as described in the notes of Tables 13-15. Each specification includes HRS and O*NET measures of a comparable job attribute. Standard errors are clustered at the individual level and reported in parentheses. ${ }^{* * *},{ }^{* *}$, and $*$ indicate significance at the $1 \%, 5 \%$, and $10 \%$ level, respectively. 
site effect. This may indicate that these two indices are likely measuring different attributes. Objective on-the-job responsibility decreases the probabilities of working after ages 62 and 65, but has no impact on planned retirement age. Self-reported difficulty/stress shortens time until planned retirement, while increasing the self-reported probability of working full-time after age 62. These effects are apparent even when objective measures of responsibility and difficulty/stress are controlled for.

\section{Conclusions}

In this paper we investigate the extent to which nonmonetary work-related factors influence employment transitions at older ages and retirement intentions. By leveraging the wealth of information about older workers available in the Health and Retirement Study (HRS) and the rich set of occupation-specific descriptors provided by the Occupational Information Network $\left(\mathrm{O}^{*} \mathrm{NET}\right)$, we identify which nonmonetary job characteristics lead full-time employees to remain employed full-time, or to move to part-time, retirement, or to unemployment/out of the labor force. We also study how these nonmonetary job attributes shape individual expectations about working in the future and planned retirement ages. To disentangle the effect of nonmonetary job characteristics on labor-supply decisions and retirement expectations from other potential determinants, we control in our empirical analysis for basic demographics and for a wide range of potential confounders.

Specifically, we account for monetary job characteristics and institutional incentives, such as hourly wage, existence and type of employer-sponsored pension plan, employerprovided health insurance policy, indicators for whether the individual is above the age of 62 (eligible for early claiming of Social Security benefits) and 65 (Medicare eligibility). We also control for the age difference with the spouse and an indicator for whether the spouse is working. We proxy individual ability to work with self-reported health status and cognitive test scores. Finally, we include individual-specific characteristics that may shape retirement preferences, such as the Big Five personality traits (openness to experience, conscientiousness, extraversion, agreeableness, and neuroticism), attitude toward risk and financial timeline for planning family spending and savings. Keeping all these factors constant, we assess the effect of individuals' 
perceptions of job characteristics, as well as of objective job attributes on labor supply decisions and retirement plans.

We find that in most domains both subjective and objective measures of job characteristics are important drivers of labor-supply decisions at older ages and contribute to determine the path to retirement. Objective measures are more strongly and robustly associated with transitions from full-time work to retirement, as well as with retirement intentions. Subjective measures are more often related to the decision of moving to part-time and correlate less strongly with expected retirement age and subjective probabilities of working after age 62 and 65 .

While we have robust evidence of the extent to which job demands and work conditions influence retirement paths and plans, our analysis is still preliminary in its attempt to uncover causal relationships: unobservable individual characteristics responsible for sorting into specific occupations may also shape retirement decisions. By exploiting biomarkers, retrospective information on early life environment and attitudinal questions about other individual traits not accounted for in the current analysis, we aim to refine our study and infer the causal link between nonmonetary job attributes and the nature/timing of retirement. Knowledge of these parameters will inform the debate on how improvements in working conditions may prolong attachment to the labor force and contribute to the sustainability of Social Security programs and economic growth. 


\section{References}

Angrisani, Marco, Michael D. Hurd, Erik Meijer, Andrew M. Parker, and Susann Rohwedder. 2013. "Labor force transitions at older ages: the roles of work environment and personality." Working Paper No. WP 2013-295. Ann Arbor, MI: Michigan Retirement Research Center.

Bartel, Ann P. 1982. "Wages, Nonwage Job Characteristics and Labor Mobility.” Industrial and Labor Relations Review, 35(4), pp. 578-589.

Blekesaune, Morten and Per Erik Solem. 2005. "Working Conditions and Early Retirement." Research on Aging, 27(1), pp. 3-30.

Chien, S., et al. 2014. RAND HRS data documentation, Version N. Santa Monica, CA: RAND Corporation.

Cobb-Clark, Deborah A. and Stefanie Schurer. 2012. “The stability of big-five personality traits.” Economics Letters, 115, pp. 11-15.

Currie, Janet and Brigitte C. Madrian. 1999. "Health, Health Insurance and the Labor Market.” In Handbook of Labor Economics, D. Card and O. Ashenfelter (eds). Amsterdam: North Holland, pp. 3309-3407.

Duckworth, Angela and David Weir. 2010. "Personality, lifetime earnings, and retirement wealth.” Working Paper No. WP 2010-235. Ann Arbor, MI: Michigan Retirement Research Center.

Filer, Randall K. and Peter A. Petri. 1988. “A job-characteristics theory of retirement.” The Review of Economics and Statistics, 70(1), pp. 123-128.

Gruber, Jonathan and David A. Wise (eds.). 2004. Social Security Programs and Retirement around the World: Micro-Estimation, Chicago, IL: University of Chicago Press.

Hayward, Mark D., William R. Grady, Melissa A. Hardy, and David Sommers. 1989. “Occupational Influences on Retirement, Disability, and Death.” Demography, 26, pp. 393409.

Hurd, Michael D. and Kathleen McGarry. 1993. "The Relationship between Job Characteristics and Retirement.” Working Paper No. 4558. Cambridge, MA: National Bureau of Economic Research. 
Krueger, Alan B. and David Schkade. 2008. ”Sorting in the Labor Market: Do Gregarious Workers Flock to Interactive Jobs?” Journal of Human Resources, 43(4), pp. 859-883.

Lucas, Richard E. and Brent M. Donnellan. 2011.”Personality Development Across the Life Span: Longitudinal Analyses With a National Sample From Germany.” Journal of Personality and Social Psychology, 101, pp. 847-861.

Lumsdaine, Robin L. and Olivia S. Mitchell. 1999. "New Developments in the Economic Analysis of Retirement." in Handbook of Labor Economics, D. Card and O. Ashenfelter, eds., Amsterdam: North Holland, pp. 3261-3307.

Maestas, Nicole. 2010. "Back to Work Expectations and Realizations of Work after Retirement.” The Journal of Human Resources, 45(3), pp. 718-748.

Manski, Charles F. 2004. “Measuring Expectations.” Econometrica, 72(5), pp. 1329-1376.

Quinn, Joseph F. 1978. “Job Characteristics and Early Retirement.” Industrial Relations, 17(3), pp. 315-323. 